\title{
REGIONAL WINE REPUTATION: HOW IT INFLUENCES TRADE AND CONSUMER PURCHASING BEHAVIOR
}

\author{
A Thesis \\ presented to \\ the Faculty of California Polytechnic State University, \\ San Luis Obispo
}

In Partial Fulfillment

of the Requirements for the Degree

Master of Science in Agribusiness

by

Joseph Bernard Ostrander

December 2015 
(C) 2015

Joseph Bernard Ostrander

ALL RIGHTS RESERVED 


\section{COMMITTEE MEMBERSHIP}

TITLE:

AUTHOR:

DATE SUBMITTED:

COMMITTEE CHAIR:

COMMITTEE MEMBER:

COMMITTEE MEMBER:

COMMITTEE MEMBER:

COMMITTEE MEMBER:
Regional Wine Reputation: How it Influences Trade and Consumer Purchasing Behavior

Joseph Bernard Ostrander

December 2015

Marianne Wolf, Ph.D.

Professor of Wine Business

William Amspacher, Ph.D.

Professor of Wine Business

Jerusha Greenwood, Ph.D.

Associate Professor of Recreation, Parks, \& Tourism Administration

Lindsey Higgins, Ph.D.

Assistant Professor of Agribusiness

Eivis Qenani, Ph.D.

Professor of Agribusiness 


\section{ABSTRACT \\ Regional Wine Reputation: How It Influences Trade and Consumer Purchasing Behavior}

\section{Joseph Bernard Ostrander}

What are wine trade buyers and wine consumers willing to pay for a bottle of wine based on the reputation of the grape growing region apart from existing corporate branding image, variety popularity, or accolades from industry periodicals and celebrity wine critics? Results from a previous study discovered how attitudes about place-of-origin influenced consumer perceptions regarding the quality associated with the wines from that region. Related research also looked at how wine prices depended on the quality associated with a wine region's reputation when linked to older, and better known wine regions from different countries. The purpose of this research was to examine the attitudes of wine trade buyers and wine consumers to determine how much of an influence selected California wine regions have on their purchasing decisions.

A trade survey was conducted during November and December 2014 and sent via email to 1,778 wine trade contacts that were provided by a well-known winery in San Luis Obispo County. Final responses numbered $152(8.5 \%)$ from trade businesses located in the U.S. The majority of participants were from Florida (24\%) and California (22\%), with $71 \%$ being onpremise sales channels while $29 \%$ were retail off-premise outlets.

Respondents to the trade survey were asked to rank eight different desirability factors about the wines they selected for resale. The two most desirable features indicated were: 1) Premium quality product; and 2) Grapes from a respected growing region. However, the choice of wine From a well-known AVA, was only a somewhat to very desirable trait. This could suggest that the wine trade is either unaware or unsure of what an AVA is. Of the 152 wine trade respondents that were asked how often they make a decision to purchase one wine versus another based on where it was produced, $43 \%$ indicated they always, or very often do so. Moreover, $81 \%$ of the trade respondents indicated that a wine's place-of-origin did influence their purchasing decision at least somewhat often.

A related survey involving 302 wine consumers was conducted in San Luis Obispo County during October 2014 and February 2015. Responses were collected outside selected grocery stores using the personal interview method. The survey demographics of those consumers that participated in the study were similar to the MRI+ statistics of domestic wine consumers, although there was a higher proportion of younger respondents in the current sample.

Wine consumers were also asked to rate six different features by desirability when making a decision to purchase wine. The two most desirable features indicated by respondents were: 1) Good value for the money; and 2) Varietal I like. However, wine selected From a respected region, was considered only a somewhat desirable trait. These findings were not surprising since $16 \%$ of the total consumers also indicated they did not know the place-of-origin of the wines they purchased. Likewise, $60 \%$ of consumers always, or very often Read the label to learn where the wine was produced, while only $38 \%$ indicated they always, or very often Make a decision to purchase one wine versus another based on where the wine was produced.

Results suggest that for the typical wine consumer the grape growing region is not an important factor when making a purchasing decision. Conversely, wine trade decision makers do consider a wine's place-of-origin an important factor when they select wines for their restaurants, wine bar menus, and outlet shelves. Consequently, wine regions should prioritize efforts toward educating the wine trade by highlighting the quality of their area's winegrowing practices. 


\section{ACKNOWLEDGMENTS}

This thesis would have remained little more than just a daydream had it not been for the skilled diplomatic approach of my committee chair, Dr. Marianne Wolf, when she convinced me to collaborate with her on the scope of this study in favor of pursuing my original thesis concept. I consider it an extreme pleasure, and incredible honor, to have worked with you on this project that represents the essence of wine marketing principles applied to a very relevant theme. It is my hope this resulting effort aptly reflects the standards of excellence you encourage all of your students to achieve during their academic adventures.

I wish to express my deepest gratitude to Professor William Amspacher, Ph.D., who accepted my request for consideration into the Agribusiness graduate program without hesitation. Your understanding, thoughtfulness and encouragement during the immense challenges I encountered the first year of my later-in-life academic adventure cannot be underestimated. This dissertation would not have been possible without you giving me the opportunity to reenter the hallowed halls of higher education, and prove that contrary to sage wisdom, this older graduate student could definitely learn new wine business concepts.

Dr. Lindsey Higgins: what can I say? Your incredible patience with this older graduate student as he struggled to incorporate what were then foreign wine business principles into my later-in-life educational experience did not go unnoticed. When my learning curve was steepest, you assuaged my fears and continued to believe in my ability to successfully integrate those new concepts into my graduate student journey. Thank you so much for your sensitive encouragement that was offered at a time when I needed it the most.

To Dr. Jerusha Greenwood: many thanks for agreeing to be on my committee. The inclusion of a RPTA 400 level class into my formal study plan was intended to be a possible substitute for one of my AGB 500 level requirements. Despite the outcome, I found the class to be very informative, highly enjoyable, and a valuable addition to my well-rounded wine business educational undertaking.

Dr. Qenani: your last minute addition to my committee was definitely a welcomed one. Thank you so much for your gracious encouragement, enthusiasm, valuable input, and assistance with the technical challenges that ensured every lower case " $\mathrm{j}$ " was dotted, and every lower case " $\mathrm{t}$ " was crossed as I neared the end of my academic accomplishment.

And to my cherished support "team" of dear family and friends that believed in me, encouraged me, visited me, commiserated with me, and maintained a regular connection with me...I humbly salute you. Wow. Although my name appears as sole author of this thesis, in reality it should read: Joseph's Team. Words cannot adequately express my heartfelt gratitude. Thank you so much for helping me complete this amazing academic adventure of a lifetime.

Lastly, I wish to dedicate this incredible personal achievement to the memory of my beloved mother, Irene Flora Ostrander...I did it mom!

Saude! 


\section{TABLE OF CONTENTS}

Page

LIST OF TABLES viii

\section{CHAPTER}

I. INTRODUCTION

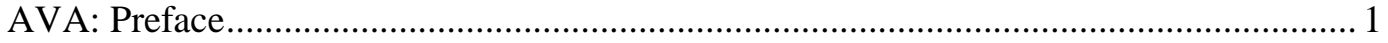

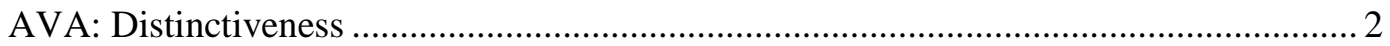

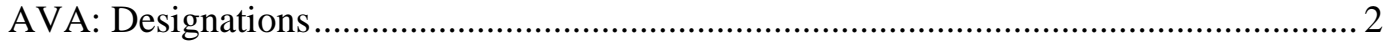

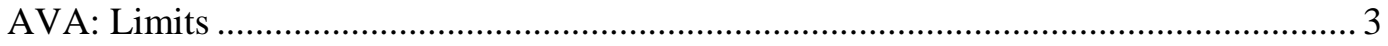

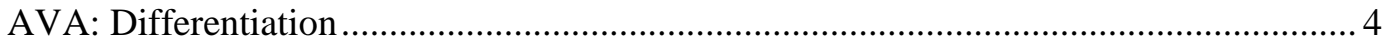

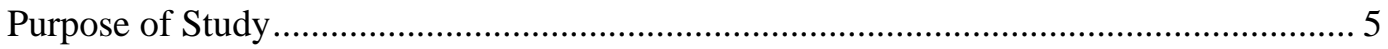

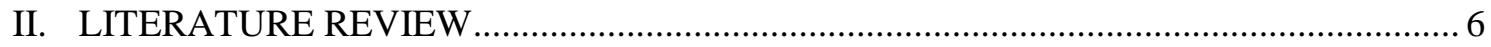

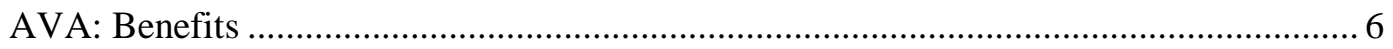

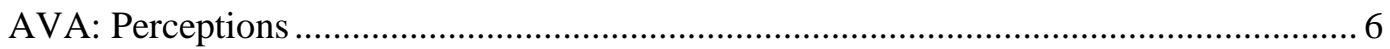

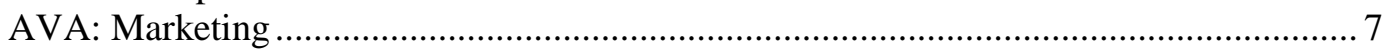

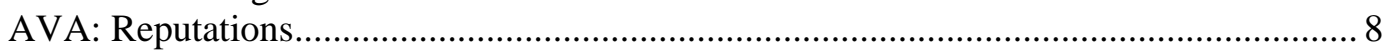

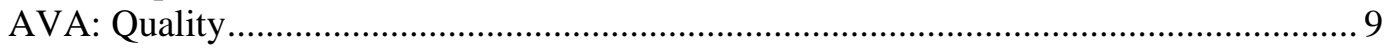

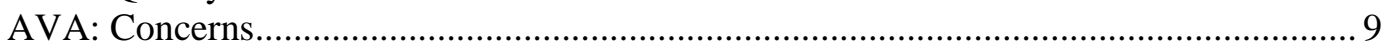

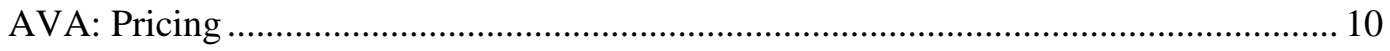

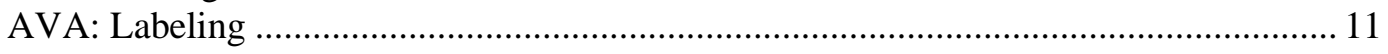

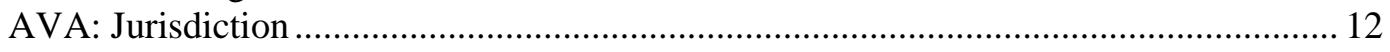

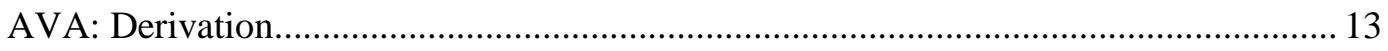

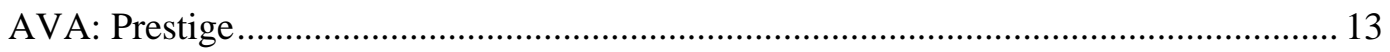

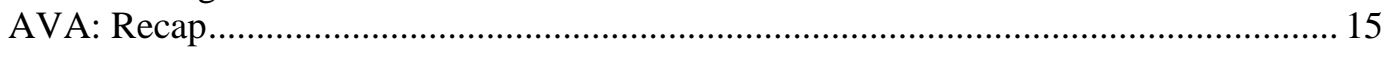

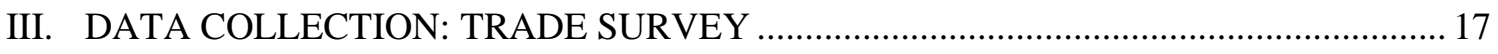

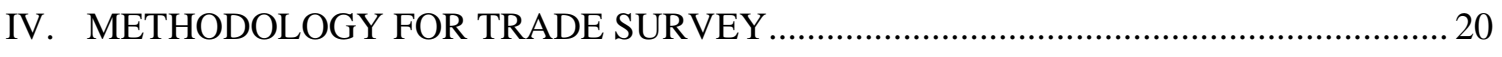

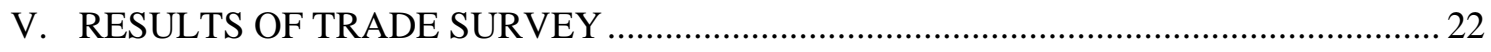

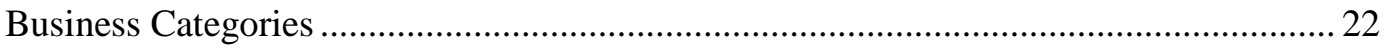

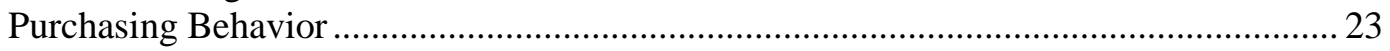

Attitudes Toward Wine Regions............................................................................ 24

Attitudes Toward Wine Characteristics .......................................................................... 27

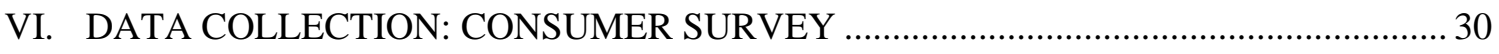

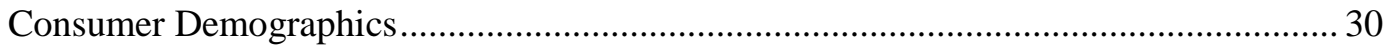

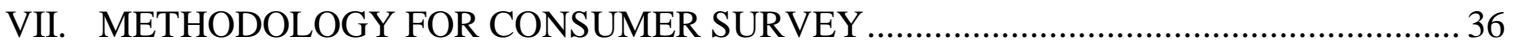

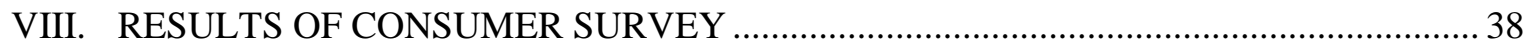

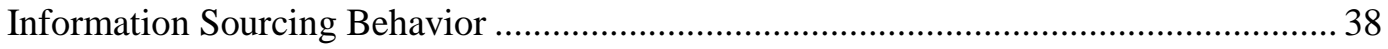

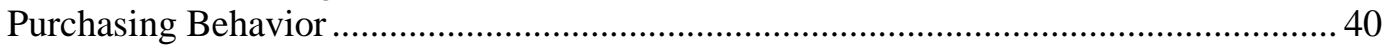

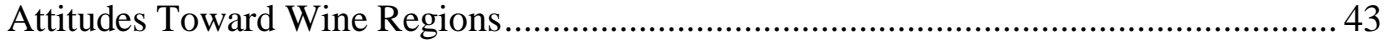




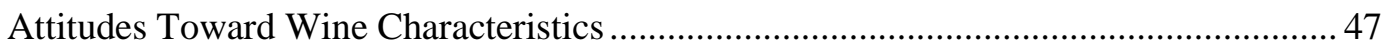

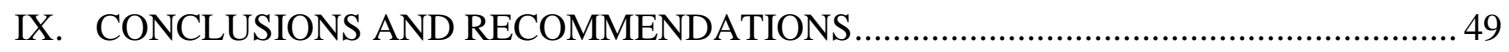

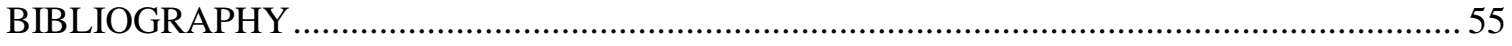

APPENDICES

A. Wine Trade Survey Questionnaire ………............................................................. 57

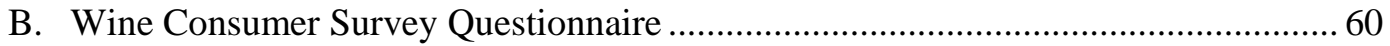




\section{LIST OF TABLES}

Table

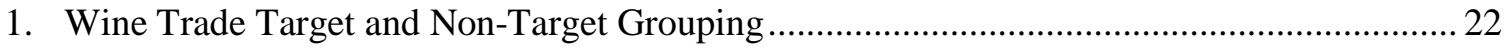

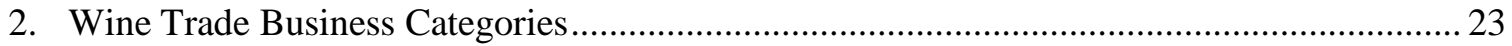

3. Wine Trade Beverage Types Selected for Resale .............................................................. 23

4. Wine Trade Varietals and Blends Selected for Resale ........................................................ 24

5. Wine Trade Purchases by Region................................................................................. 24

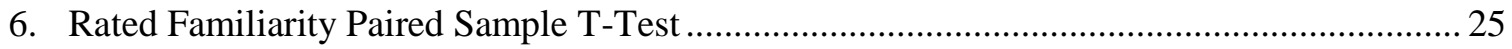

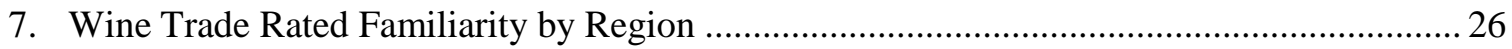

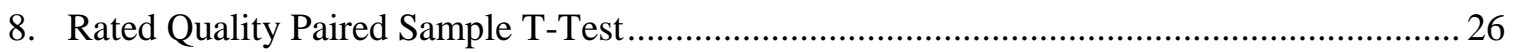

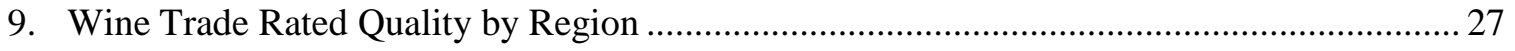

10. Rated Desirability Features Paired Sample T-Test................................................................. 28

11. Wine Trade Rated Desirability Features …..................................................................... 29

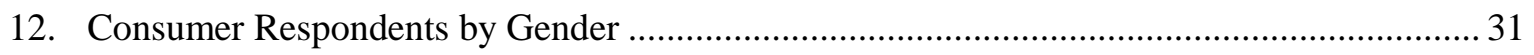

13. Consumer Respondents with Children in Household ....................................................... 31

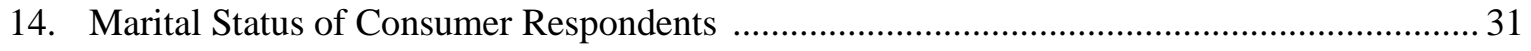

15. Age Range of Consumer Respondents ...................................................................... 32

16. Education Level of Consumer Respondents ................................................................. 32

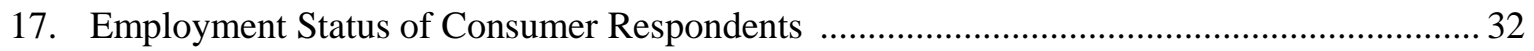

18. Income Range of Consumer Respondents ................................................................. 33

19. Wine Consumer Target and Non-Target Grouping............................................................ 38

20. Wine Label Readers Target and Non-Target Grouping ....................................................... 39

21. Wine Information Sources of Consumer Respondents ...................................................... 39

21. Wine Information Sources of Consumer Respondents (cont'd) .......................................... 40

22. Types of Alcoholic Beverages Consumers Purchased ....................................................... 40 


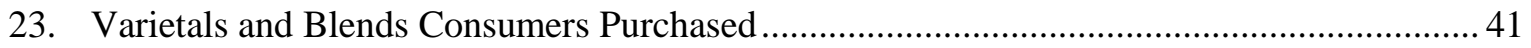

24. Number of Wine Bottles Purchased Monthly ...................................................................... 41

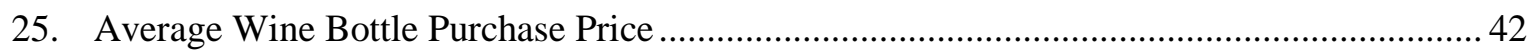

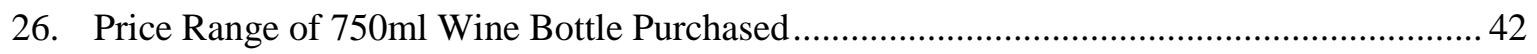

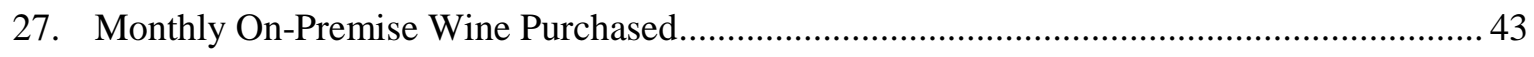

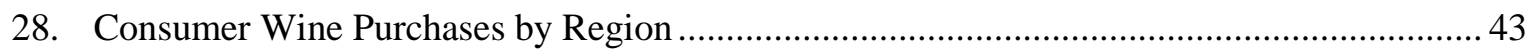

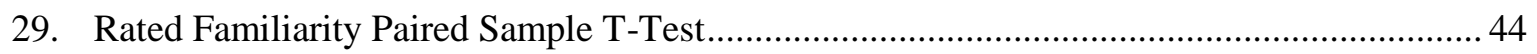

30. Consumer Rated Region Familiarity............................................................................. 45

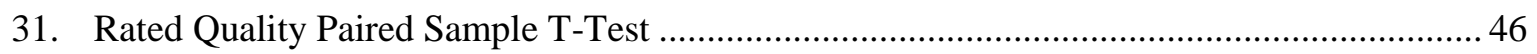

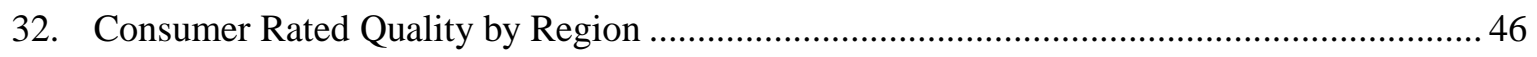

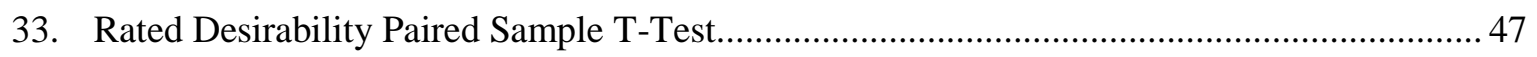

34. Consumer Rated Desirability Features .......................................................................... 48 


\section{INTRODUCTION}

Before the legendary 1976 Judgment of Paris retold in the movie Bottle Shock, Napa Valley wines were virtual unknowns in California let alone the rest of the world. It was during this one decisive event deemed the proverbial, "cork pop heard "round the world," that Chateau Montelena's 1973 Chardonnay and Stag Leap's 1973 Cabernet Sauvignon bested their French counterparts in a blind tasting that stunned U.S. winemakers and consumers alike. The effects of the 1976 Paris Blind Tasting were immediate; this single event put the international spotlight on Napa Valley, and California's nascent wine making reputation was birthed. As impressive as this

one event was it needs to be viewed realistically; the regional wine reputation of the Napa Valley, like Rome, was not built in a day. After setting aside rosé filled wine glasses, the historical facts reveal it took decades for Napa Valley to become the renowned wine region it is today.

For both the wine trade and the typical wine consumer, does the reputation of California wine regions impact their buying choices? What can be determined from how the wine trade perceives the reputation of wine regions, and how the typical wine consumer evaluates those same areas? Wine trade decision makers ultimately choose which wines pass through the distribution channels into on-premise and off-premise outlets. It is reasonable to assume regional winegrowers can take advantage of knowing which features influence the buying decisions of both the wine trade gatekeepers and wine consumers alike.

\section{AVA: PREFACE}

Vineyards and wineries residing within a certified winegrowing region can benefit from its distinctiveness when the developing reputation of that region reflects the perceived quality of the grapes and/or the wines produced there. Consequently, do established American Viticultural Areas (AVAs) influence purchasing behaviors based on how they are appreciated by both the trade and consumers making wine buying decisions? If regional wine reputations do have a 
perceptible influence on the purchasing habits of both the trade and consumer, then it is necessary to understand what an AVA is. How is such an established area defined, and what does it—or equally important—what does it not signify.

\section{AVA: DISTINCTIVENESS}

The official term for an established winegrowing region in the United States is called an American Viticultural Area instead of the less defined region commonly regarded as an appellation. Not to confuse matters, but an AVA is considered a type of appellation and the terms are often used interchangeably. However, not all appellations are established AVAs. AVAs are the approved grape growing regions that have been designated by the Alcohol and Tobacco Tax and Trade Bureau (TTB). Vineyards or wineries located within an established AVA are not required to reference this place-of-origin identifier, but if a winery does mention an AVA on its label then at least $85 \%$ of the grapes going into the wine have to be sourced from that same AVA (TTB, 2012).

AVAs are distinct geographic areas that share similar climatic conditions, soil types, elevation and comparable properties that contribute certain desirable characteristics to the wines produced from grapes grown there. It is also important to note that just because grapes or wine are from a designated AVA, such provenance does not make any claims about quality since quality perceptions are entirely subjective. However, an appreciative group of wine consumers, together with accolades from wine industry personalities, can boost the status of one region over another.

\section{AVA: DESIGNATIONS}

Almost any geographic area within the United States can be considered a potential AVA as described on the official TTB application, but existing state and county boundaries cannot be defined as AVAs even if they can be identified as a wine's source. For example, Napa County, or the State of California, cannot be considered an AVA, but they can be referred to as appellations 
of origin. The AVA designation highlights a local area, known by a particular name, which is associated with a characteristic grape growing area. Subdivided AVAs can be designated inside larger AVAs, such as the creation of eleven new AVAs within the existing Paso Robles AVA in San Luis Obispo County, CA (TTB, 2012). Jason Haas, general manager of Tablas Creek

Vineyard and Paso Robles AVA Committee member explained the significance of the TTB's

final ruling effective November 10, 2014:

These new AVAs will be a powerful tool for wineries to explain why certain grapes are particularly well suited to certain parts of the appellation, and why some wines show the characteristics they do while other wines, from the same or similar grapes, show differently. Ultimately, the new AVAs will allow these newly created sub-regions to develop identities for themselves with a clarity impossible in a single large AVA (11 new viticultural areas established within Paso Robles, 2014).

Steve Lohr, CEO of J. Lohr Vineyards \& Wines concurred:

Our AVA is an incredibly diverse region that has taken its rightful place on the world wine stage. These sub appellations will allow growers and vintners to tell their stories more clearly, which in turn will give consumers and the trade a much greater understanding of Paso's diversity and complexity. Prior to this, Paso Robles was the largest non-county California AVA not currently subdivided. It is also an area with more diversity of rainfall, soils and climate than almost any other comparably sized region. We have been a great believer in this initiative since the beginning, and are proud that it has been accomplished in a way that will strengthen the Paso Robles brand with conjunctive labeling (11 new viticultural areas established within Paso Robles, 2014).

As of March 24, 2015, the TTB has defined 230 AVAs in the United States in response to requests from wineries and other petitioners. These official AVAs range in size from the largest, the Upper Mississippi Valley AVA at 29,914 square miles with boundaries extending into four states (Cattell, 2009), to the smallest, the Cole Ranch AVA located in Mendocino County, CA, at only 253 acres (Esterlina Vineyards \& Winery, 2015).

AVA: LIMITS

The AVA designation does not limit the type of grapes cultivated, crop yields, or the chosen methods of vinification, even though these factors can be reasons a petitioner uses to 
highlight the distinctiveness of any proposed new AVA. However, current regulations do impose the following conditions when petitioning for a new AVA: 1) historical reference associated with the name of the proposed new AVA area that is locally or nationally recognized; 2) additional evidence that the desired boundaries are legitimate; and 3) evidence supporting the uniqueness of the growing conditions that identifies annual climate data, soil types, elevation and other physical features. Every petition must also contain a detailed USGS map that defines, and clearly illustrates, the prospective boundaries (TTB, 2012).

\section{AVA: DIFFERENTIATION}

Only through differentiation can a single wine operation distinguish itself from the crowded wine market that continues to be overwhelmed by a proliferation of wine brands today. Once regarded as a luxury good consumed by an exclusive club, the introduction of affordable wine brands has resulted in greater availability to a growing segment of increasingly savvy consumers (Bruwer and Wood, 2005). These consumers have a greater interest in the details about their wine's place-of-origin because they place more value on wines that come from specific regions versus those with only a generic provenance. As a result, regional brand reputations are becoming ever more relevant to the wine trade and the wine consumer alike.

Wine marketers today have a daunting selection of larger wine regions and smaller subappellations to choose from when deciding to place this information on their labels. And with these sometimes bewildering choices three considerations must be weighed: which regional identity is more highly regarded; does it translate into higher prices for grape growers and wine producers; and ultimately, does it result in higher retail prices for the typical wine consumer. Or more simply stated, will the trend toward dividing up larger wine regions into smaller AVAs automatically result into more profitable marketing options for both the grape grower and wine producer? 


\section{PURPOSE OF STUDY}

The objective of this research is to determine if the reputation of selected California wine regions have an impact on the purchasing decisions of both the wine trade and the typical wine consumer. The majority of marketing research regarding purchasing behavior typically focuses on the consumer's buying motivation. However, in this study, the inclusion of the wine trade was deliberately made to gain a better understanding of how regional wine reputation also influences their purchasing decisions. Since the retail wine trade acts as the gatekeeper in the three-tier distribution system, it is critical to understand what affects their buying choices since they ultimately determine what wines eventually make it into the on-premise and off-premise distribution channels. If the retail wine trade decision makers choose which wines appear on outlet shelves, restaurant wine lists, and wine bar offerings, it would benefit regional winegrowers to know what features are most important to these gatekeepers. This knowledge could then be used to allocate resources more effectively toward educating the trade about a region's grape growing quality and promoting the area's winemaking artistry. Similarly, having a better grasp of the perceptions and preferences motivating the purchasing behaviors of typical wine consumers would also be particularly advantageous to the wine trade. 


\section{LITERATURE REVIEW}

\section{AVA: BENEFITS}

Marketing strategy implications for the small winemaker facing stiff brand competition in a crowded marketplace was addressed by Jarvis and Goodman (2005). The researchers aimed to clarify how a true small-scale wine producer differentiated itself from its competitors as compared to only being regarded as a boutique, small volume provider. Jarvis and Goodman (2005) looked at what was considered a niche product versus a change-of-pace product depending upon the price point and how the wine was actively being marketed. Change-of-pace products are items selected by consumers simply to provide variety from their usual or preferred brands. Such products are infrequently purchased and do not become permanent substitutes for the consumer's favored brand. Jarvis and Goodman (2005) concluded that small lot wine producers do not automatically qualify as niche-market suppliers, and the option to supply change-of-pace offerings are usually unsustainable for those smaller producers. The authors pointed out that only larger wineries with ample marketing resources are able to provide changeof-pace options successfully (Jarvis and Goodman, 2005). Due to promotional budget constraints and product line limitations, it is important for smaller boutique winemakers to identify with something that has more branding clout than just being recognized as another niche-market supplier. By promoting an existing AVA, and/or the more expansive wine region, smaller wineries have a low-cost option that can take advantage of existing wine area reputations.

\section{AVA: PERCEPTIONS}

Expanding upon the concept of product differentiation in a congested wine market, Johnson and Bruwer (2007b) looked at how regional brand image impacts consumer perspectives. They mentioned how some marketing pundits thought a wine's place-of-origin was being underutilized as a good promotional tactic to help differentiate brands. Since the international wine 
community has codified specific wine regions with respect to unique growing conditions, or terroir $^{1}$, highlighting place-of-origin has become a common strategy when differentiating wines from larger regions, sub-regions and smaller appellations. Johnson and Bruwer (2007b) underscored the buying behavior of savvy consumers that were willing to pay higher prices for wines from better known regions, which means brand image and customer perception of quality is important to both the consumer and the regional wine producer alike.

\section{AVA: MARKETING}

Bruwer and Johnson (2010) continued to explore how wineries highlight the place-oforigin in their branding efforts. Findings indicated that consumers utilized regional branding cues, along with unique descriptions and images, when evaluating comparable wine labels. The inclusion of regional information on the wine label seemed to influence buyer confidence in product quality in almost every survey response. Since the domestic and foreign wine market is bloated with a mind-boggling array of wine brands, this vast assortment can be overwhelming to the average consumer. Bruwer and Johnson (2010) pointed out that despite this overabundance of choices, sectors within the industry were trying to be noticed by creating strong brands commanding customer loyalty. An earlier study also looked at the rather intricate wine purchase decision process in greater detail (van Ittersum, 2003). Since consumers can be inundated by the sheer complexity of the buying situation that results from so many wine brands to choose from, place-of-origin is widely accepted as one of the key strategies to highlight such distinction (Bruwer and Johnson, 2010). This is the situation in California where provenance has become an integral part of regional wine branding strategies. The marketing strategies within a regional branding context is directly related to the efforts to create and expand American Viticultural Areas (AVAs). The authors mentioned how the formation of early AVAs was often done

\footnotetext{
${ }^{1}$ n. terroir is a French term for a group of vineyards (or even vines) from the same region, belonging to a specific appellation, and sharing the same soil type, weather conditions, grape varieties and wine making know-how, all of which contribute to the unique personality of the wine.
} 
haphazardly within a compressed timeline, which added complexity and confusion to subsequent wine branding efforts (Bruwer and Johnson, 2010).

Bruwer and Johnson (2010) also maintained there are many analysts in the wine industry who believe in the value of specific appellations; consensus within the industry supports the conclusion that an AVA alone is able to command more worth in the marketplace. However, the results of their study show there was an overarching halo effect given off by the larger, better known regions when an individual AVA was not as familiar (Bruwer and Johnson, 2010).

\section{AVA: REPUTATIONS}

There are conflicting attitudes about the benefits of, or even the need for AVAs when this information is referenced on wine labels and used in promotional campaigns. Bruwer and Johnson (2010) acknowledged that a single AVA alone can be enough for the smaller percentage of high spending and more knowledgeable consumers, but for those that are not as well-informed it can just as easily cause confusion and a weakening of the place-of-origin impact. Bruwer and Johnson (2010) also pointed out how the reasoning for establishing a new AVA can be rather trivial; it can be as generic as whether the proposed name is known locally, regionally or nationally. Yet the designation is only an effort to capitalize on historic familiarity and should be understood that grapes sourced from a newly established AVA do not automatically infer anything about the fruit or wine quality. In order for new AVAs to have an economic benefit for wineries and vineyards within its borders, there must be significant relevance of the sub-region to existing and future wine consumers. Part of the study explored the impartiality of a larger wine region and the appellations established within it. Bruwer and Johnson (2010) found that the larger wine region designation with its greater historical identity had a stronger awareness than the smaller, subdivided AVAs later established within it. Consumer attitudes were determined when two choices were offered: 1) wine labels that only included an AVA designation; versus 2) wine labels that mentioned both the greater wine region name and the sub-region AVA. Findings 
revealed that savvy consumers preferred the wine labels with both the larger region and the smaller appellation designations, versus labels that only included the sub-region AVA descriptor. The results provided significant insight into regional wine branding efforts and the influence it has on consumer wine purchasing habits.

AVA: QUALITY

Johnson (2011) looked at how the Napa Valley AVA has become a highly touted branded entity that has been effectively marketed. The popularity of Napa Valley as a wine tourism destination affords financial benefits for all related businesses in the area. Even Napa Valley's renowned wine reputation spills over to other agricultural products from the region, such as olive oil and cheese. Simply having the name Napa County, or Napa Valley on the label carries with it the implication of quality and is a good example of how a wine region's reputation directly impacts market pricing for wine as well as other products from the region. Johnson (2011) also included results from a collaborative study with Johan Bruwer, of the University of Adelaide, about related findings of AVAs within Sonoma County. Johnson recapped how AVAs here in the United States were intended to mirror the celebrated appellation system of France, and their associated reputation of implied quality.

\section{AVA: CONCERNS}

Although the TTB officially defines wine regions, it does not claim such regulatory recognition imparts any commercial advantage to those areas (TTB, 2012). Consumer endorsement is what influences the intrinsic value of an AVA rather than the inferred approval from a governmental agency. As more of the larger wine regions are being subdivided into smaller sectors, concerns from wine industry observers question how this terroir gerrymandering benefits wine consumers. More than fifteen years ago, Jack Cakebread of Cakebread Cellars voiced his concern with the trend, as well as similar concerns raised ten years ago by John Gladstones, researcher at UWA, regarding the possibility of carving up Australia's Margaret 
River wine region into newer, but less well-regarded subdivisions. Johnson (2011) asserted there is an implied suggestion of quality when an AVA is listed on a wine label, and such disclosure is meant to convince the consumer that the wine is worth more. If the financial benefits seem worth it to vineyards and wineries that refer to AVAs in the marketing and labelling of their grapes and wines, then Johnson (2011) also cautioned there must be added value associated with the AVA that already has sufficient marketplace momentum. Napa Valley was used as an example of how problems arise whenever AVAs become a significant influence on grape and wine prices. The history of this storied wine region and how its original geographic area was established, then expanded, and eventually subdivided, reveals there is no permanent magic marker method of defining the Napa Valley. The author also pointed out how politics and acrimony will always be part of Napa County's legacy due to the understandable resentment of vineyard owners located just outside the coveted Napa Valley AVA’s boundary lines (Johnson, 2011).

\section{AVA: PRICING}

Rickard, McCluskey, and Patterson (2015) developed an experiment using auction data to evaluate responses of consumers that had been privy to additional information linking U.S. wine regions to well-known French wine appellations, an influence they coined as reputation tapping. Their experiment focused on the following domestic wines: 1) Chardonnay from California, Oregon and Virginia; 2) Pinot Gris from California and Oregon; and 3) Viognier from California and Virginia. These wines were specifically chosen from seven AVAs in the U.S. that could reasonably be compared to similar appellations in France. Information associating the terroir of the French region with its U.S. counterpart was shared with one subset of test subjects prior to their auction participation. Linking the French appellations with domestic AVAs was shown to increase the auction bids for wines from newer U.S. wine regions that were becoming more recognizable. Since consumers are more likely to pay higher prices for products from reputable firms or regions, riding the coattails of established quality perceptions could help boost awareness 
of lesser-known regions. In their study, Rickard, et al. (2015) pointed out that regional reputations have an impact on wine prices and how lesser-known wine regions can integrate reputation tapping references to denote quality, and speed up the reputation building process. Rickard, et al. (2015) also mentioned how their research was inspired by popular California wine festivals linking local wine regions to their European counterparts. The Hospice du Rhône event held in Paso Robles, CA, and the Alsace Festival in Anderson Valley, CA, were cited as two examples of making obvious references to French wine regions that were meant to highlight locally produced wines. The primary focus of their study was to determine if there was a measurable influence from associating Old World wine regions, known for their quality, with more recent New World winegrowing regions (Rickard, et al., 2015). Did the phenomena of reputation tapping have any affect? The results of their study indicate how the quality reputation from an emerging AVA may be minimal, while information describing the AVA coupled with a reference to a famous region in France can positively influence the consumer's perception of quality (Rickard, et al., 2015).

AVA: LABELING

Atkin and Newton (2012) looked at how the 16 subdivided AVAs within California's Sonoma County were used to promote the wines produced there. This well-known wine region was said to be home to 350 wineries supplying nine percent of California's wine production. The authors pointed out how wineries in Sonoma County emphasize a collective place-of-origin as a means to increase visibility and attract consumer attention (Atkin and Newton, 2012). Such a successful differentiation approach mirrors one used by the winegrowing areas of the Napa Valley, the Central Valley's Lodi region, and the Central Coast's Paso Robles region. This collaborative promotional strategy called conjunctive labeling, was also explored at length by Sonoma County vintners before they approved their own initiative which was passed in January 2011, and effective at the beginning of 2014. The resulting legislation, supported by Sonoma 
County's wine industry associations, required the word "Sonoma County" to appear on the label of any wine that also referenced an AVA located within the county.

In response to fears that consumers may not recognize smaller AVAs, the decision to have the front labels of all Sonoma County wines display both the overall county region and AVA was meant to preserve the synergy of the larger regional cluster while limiting consumer confusion. International winemaker and consultant, Nick Goldschmidt, expressed a similar sentiment during a Napa Valley winegrower's seminar. He underscored the importance of including appellations, but only while promoting the whole Napa Valley. Goldschmidt felt this approach preserved Napa's better known wine region's power of influence (Franson, 2011).

\section{AVA: JURISDICTION}

The California Department of Alcoholic Beverage Control (ABC) is the state regulatory agency governing conjunctive labeling compliance. This state agency will also assist in designing a new wine label prior to its submission to the TTB for approval. Preserving the collective wine region identity was intended to build brand equity and drive wine sales without diluting the overall regional quality reputation by only referencing more obscure AVAs. Because consumers typically use a variety of information along with previous experience when making wine purchases, the inclusion of both the greater and lesser places-of-origin on the wine label remains a key marketing strategy for many wineries.

Realizing the impact of putting the place-of-origin on wine labels, wineries now have a powerful method of linking the perceived quality of their wines with its provenance. This simple promotional strategy leverages the product's place-of-origin and boosts its competitive position in the marketplace. Small to medium-sized wineries are not able to match the advertising reach of larger wineries, so highlighting the prominence of their local wine region is an inexpensive way to establish greater brand awareness (Atkin and Newton, 2012). However, Atkin and Newton's (2012) research suggested that the promotional focus of the larger and more familiar wine region 
with its existing quality reputation might be a more effective marketing strategy than relying solely on referencing the lesser-known AVAs within it.

\section{AVA: DERIVATION}

Johnson and Bruwer (2007a) summarized key issues highlighting relational perspectives between regional brands and their corresponding AVAs. Their findings could help winegrowing owners gain a better appreciation of the strength of their own regional brand identity. Although there is an industry consensus that larger regional wine brand identities are important, Johnson and Bruwer (2007a) felt this feature was not being fully exploited by many grape growers and wineries that only promote the smaller appellations they operate in. There is a valid concern that the trend toward carving up larger regional areas into smaller AVAs can have a diluting effect on the overarching regional brand identity. Because most of the newly established AVAs will have little immediate influence on consumer awareness and perceptions of quality, Johnson and Bruwer (2007a) recommended that winegrowers referring to those less well-known AVAs begin using the brand power synergy of the larger regions when those regions already have a positive brand image. As more AVAs garner approval, resident wineries may be tempted to distinguish themselves with the newly established sub-appellations while ignoring the larger wine region. However, Johnson and Bruwer (2007a) felt that the wine trade tendency toward promoting only newly created appellations could be less effective than identifying with existing value-laden regional reputations.

\section{AVA: PRESTIGE}

Schamel and Anderson (2003) researched the hedonic pricing of wines produced in New Zealand and Australia. Hedonic pricing is an economic model that looks at the separate price factors of products based on the assumption that the selling price is influenced by inherent characteristics of the product itself, as well as the external factors affecting it. It is a method of 
estimating value and/or demand by dividing up the researched item into its fundamental features and then estimating the contributing value of each feature.

Schamel and Anderson (2003) pointed out that premium wine production and vineyard plantings in New Zealand and Australia had grown more than 7\% annually since 1990, while wine exports had also been increasing at more than $15 \%$ for the same period. Despite this steady winegrowing capacity, per capita wine consumption in these two countries did not grow at the same rate. However, Schamel and Anderson (2003) did notice that there had been a significant substitution of quality for quantity in each of these markets. Premium (bottled) wine sales increased steadily while non-premium (cask) sales declined during the preceding decade when the study was made.

When global wine demand remains static and worldwide wine export supplies increase, it puts pressure on the average price of internationally traded wine and forces a particular group of producers to upgrade the perceived quality of its product in the mind of the consumer. For Schamel and Anderson (2003), this brought up the question of how consumers develop perceptions of quality when making the decision to purchase newly released wine. Until a wine bottle is opened and consumed, nothing can be discerned about its quality. The consumer's willingness to buy an untried wine will depend on the wine's associated reputation. More precisely, the consumer's perception of the wine's quality will be influenced by the winemaker's status, the reputation of the grape growing region, and the grape varieties that were used.

If wine consumers were uncertain about the quality of a particular wine, Schamel and Anderson (2003) assumed these consumers would be more inclined to refer to expert quality ratings when making wine purchasing decisions. Their study looked at how a consumer's willingness to pay for a particular wine was influenced by a combination of factors such as the consumer's own awareness of grape varieties along with the reputation of grape growing regions, and the quality rating of wine critics' for a particular wine or producer. Schamel and Anderson's (2003) paper analyzed the reputation and quality indicators for premium wines from New 
Zealand and Australia by examining wine critic James Halliday's data sets for nine vintages. A second set of data was also studied that consisted of more than 12,500 tasting scores of premium wines from eight vintages. From these two data sources, Schamel and Anderson (2003) were able to compare hedonic pricing model results obtained from the same base set of consumers, wines and vintages.

Schamel and Anderson (2003) made four conclusions from their study: 1) ratings by independent wine critics appeared to have a positive impact on the prices consumers were willing to pay for premium wines; 2) the price consumers were willing to pay for higher-rated wines appeared to have decreased slightly during the decade of the 1990s; 3) in Australia, there was a recognizable trend towards greater regional and varietal differentiation; and 4) compared to Australia, New Zealand had a less robust differentiation trend for both its wine regions and the selected grape varieties at the time their study was made (Schamel and Anderson, 2003).

\section{AVA: RECAP}

The various studies previously referenced addressed the following concerns pertinent to further research into wine trade and consumer purchasing behaviors: Jarvis and Goodman (2005) clarified what was considered a niche product versus a change-of-pace product depending upon the price point and how the wine was actively being marketed; Johnson and Bruwer (2007b) examined the impact regional brand image has on consumer perceptions of quality and how a wine's place-of-origin is often overlooked as a promotional tactic to help differentiate brands; Bruwer and Johnson (2010) continued to explore branding efforts featuring place-of-origin since consumers can be overwhelmed by the sheer complexity of the buying situation that results from so many wine brands to choose from; Johnson (2011) looked at Napa Valley as a prime example of an effectively marketed branded entity and how its reputation as a top wine producing region spills over to other agricultural products from the area; Rickard, et al. (2015) linked French appellations with domestic AVAs through a phenomena they called reputation tapping that was 
shown to increase auction bids for wines from newer U.S. wine regions; Atkin and Newton (2012) researched the collaborative promotional strategy called conjunctive labeling that was adopted by Sonoma County vintners requiring the county regional identifier to appear on all wine labels listing AVAs located within the county; in another study, Johnson and Bruwer (2007a) acknowledged apprehension about carving up larger wine regions into smaller AVAs that could result in diluting the overarching regional brand identity; and Schamel and Anderson (2003) looked at competitive foreign markets where there was a substitution of quality for quantity as premium wine sales increased while non-premium sales declined, and how wine critic reviews influenced the change.

As more wine regions are being subdivided into smaller sectors, concerns from wine industry observers question how terroir gerrymandering benefits wine consumers. But what about the wine trade? Although the importance of wine consumer viewpoints cannot be underestimated, the attitudes of wine trade buyers influenced by regional wine reputation has largely been ignored. It is the intent of this study to add to this scarcity of information by soliciting respondents from the wine trade to determine how regional wine reputation influences their purchasing behavior. 


\section{DATA COLLECTION: TRADE SURVEY}

The studies cited earlier in the Literature Review focused primarily on consumer attitudes and how awareness of regional wine reputation influences their buying habits. Although there is an extensive volume of published research addressing end-user purchasing behaviors, searches for comparable studies addressing the retail wine trade as a significant purchasing bloc yield far less results. The objective of this study is to ascertain if the reputation of selected California wine regions have any impact on the purchasing decisions of the wine trade, as well as those of the typical wine consumer. Due to the extensive body of research that has already been done involving wine consumer attitudes, it was the intent of this study to include a purposive convenience sample of retail wine trade contacts to ascertain what their buying habits were. How does regional wine reputation influence the wine selection criteria of gatekeepers within the thirdtier alcohol distribution system?

To achieve the research objectives, a wine trade survey consisting of 12 questions (see Appendix A) was developed by students enrolled in the Wine and Viticulture Department at Cal

Poly, San Luis Obispo, and sent via email to on-premise and off-premise business contacts known to have purchased wines for resale. This survey instrument was originally designed to determine the level of interest in a proposed new coastal AVA within San Luis Obispo County. However, only eight of the original twelve questions were considered pertinent to this study since the scope of this investigation was limited to an examination of the influence wine regions have on wine trade purchasing behavior.

The contact list was provided by a well-known winery located in San Luis Obispo County that retails wines in the $\$ 15$ to $\$ 75$ price range. The winery owners supported this study as they were keenly interested in its findings. A total of 1,778 survey requests were transmitted via email to retail wine businesses during November and December 2014. One reminder request was sent out to all non-respondents during the short data compilation window, resulting in a total 
of $152(8.5 \%)$ usable responses. Data collection occurred during the busy holiday season, which could have been a limiting factor in terms of the number of replies.

The central question to this segment of the study asked the wine trade respondents how often they made purchasing decisions based on a wine's provenance. Options consisted of a 5point rating scale as follows: $5=$ Always; $4=$ Very Often; $3=$ Somewhat Often; $2=$ Not Very Often; and $1=$ Never. Answers to this question were used to split the respondents into two groups. Those wine business buyers that indicated they always, or very often make purchasing decisions based on where the wine was produced became the target group of this part of the investigation. This group is aware of a wine's perceived value, and/or quality when it is associated with a designated geographic locale. The remaining subset, or non-target group, consisted of wine business buyers that indicated they somewhat often, not very often, or never consider place-of-origin an important factor when selecting wines for resale.

The next question on the survey addressed wine trade demographics. The respondents were asked to select the types of retail wine businesses that best described their outlet. A list of ten representative business types was supplied to choose from. Six of the listed business types were categorized as on-premise sales outlets, while four were categorized as off-premise business types.

The following combination of queries addressed wine trade purchasing behaviors. The respondents were asked to indicate what types of alcoholic beverages were offered for sale at their business the previous year. A list of seven customary categories was provided to select from. Respondents were next asked to identify which of the eleven popular wine varietals and blends listed they had purchased for resale in the past year. The respondents were also asked which wine grape growing regions the wines they had procured during the previous year originated from. A choice of seven options was provided to identify which regions were recognizable and if they had any influence on the buying habits of the wine trade respondents. The list of grape growing areas included two premier northern California regions, one renowned 
AVA located in Santa Barbara County, an extensive central coast region, and three AVAs located within San Luis Obispo County. Choosing these seven regions was twofold: the first reason was to determine if there were any differences between the influences the two well-established northern California wine regions had on wine trade purchasing behavior as compared to the more obscure up-and-coming regions of the central coast. The second reason was simply to see if the wine trade responses differed from those of the wine consumers. However, for the purposes of this study, no statistical inferences were made between the wine trade and wine consumer responses since they were treated separately. Additional choices were also included to further define purchasing behavior: None of the above; Outside the U.S.; and I DO NOT KNOW which grape growing regions my wine comes from.

The next set of questions addressed wine trade attitudes influencing the selection process when purchasing wines for resale. Respondents were asked to rate how familiar they were with the seven previously listed wine grape growing regions using a 5-point scale where $5=$ Extremely Familiar; 4 = Very Familiar; 3 = Somewhat Familiar; $2=$ Not Very Familiar; and $1=$ Not Familiar at All. The wine trade respondents were then asked to rate the quality of wines produced in those same seven wine grape growing regions, again using a similar 5-point rating scale where 5 = Excellent Quality; 4 = Very Good Quality; 3 = Somewhat Good Quality; 2 = Not Very Good Quality; and 1 = Poor Quality. Lastly, the respondents were asked to rate the desirability of eight assorted wine features when assessing suitable wine characteristics prior to purchase. Replies to this question also consisted of a 5-point rating scale as follows: $5=$ Extremely Desirable; $4=$ Very Desirable; 3 = Somewhat Desirable; 2 = Not Very Desirable; and 1 = Not Desirable at All. 


\section{METHODOLOGY FOR TRADE SURVEY}

Survey responses were entered into the SPSS program (IBM SPSS Statistics) and analyzed to determine if there were significant differences between the two groups of wine trade respondents based on demographics, purchasing behaviors and attitudes. The target group consisted of respondents that indicated they always, or very often make purchasing decisions based on a wine's provenance, while the non-target group indicated they somewhat often, not very often, or never consider place-of-origin an important factor when selecting wines for resale.

Chi-Square tests were used for all nominal and ordinal variables, while independent sample t-tests were used for all interval variables. If the P-Value $\leq 0.10$ for any of the tests, the null hypothesis asserting there was no statistically significant difference between the target and non-target groups that make decisions to purchase one wine versus another based on place-oforigin, was rejected ${ }^{2}$. Chi-Square tests were used to identify any significant differences between the target and non-target wine trade groups when comparing: 1) the ten types of retail business categories they selected that were either on-premise or off-premise outlets; 2) the purchasing behavior of the two groups that indicated which of the six types of alcoholic beverages were sold at their outlets; 3) the purchasing behavior of the two groups that selected which of the eleven specific wine varietals and blends were offered for resale; and 4) the purchasing behavior of the respondents that indicated which of the seven places-of-origin the wines they selected for resale came from.

Independent sample t-tests were used to examine if there were any significant differences between the means of the target and non-target wine trade groups for all interval variables when looking at: 1) how they rated the familiarity of the seven listed grape growing regions; 2) how

\footnotetext{
${ }^{2}$ Chi-Square test, Independent sample t-test and Paired sample t-test results are highlighted in the following manner: P-Values $\leq 0.10$, and $>0.05$, will be displayed with a single asterisk $(*)$ indicating a $90 \%$ confidence level between survey responses. Values $\leq 0.05$ will be displayed with a double asterisk $(* *)$ indicating a $95 \%$ confidence level between survey responses.
} 
they rated the quality of those same grape growing regions; and 3) how they rated the list of eight wine desirability features.

Paired sample t-tests were used to determine if there were significant differences between the eight wine desirability features the total trade sample rated, and if there were significant differences between the seven selected grape growing regions the total trade sample also rated for both familiarity and quality. If the P-Value $\leq 0.10$, then the null hypothesis asserting there were no statistically significant differences between the elements being compared was rejected. 


\section{RESULTS OF TRADE SURVEY}

During November and December 2014, a total of 1,778 requests to participate in a wine trade survey were emailed to on-premise and off-premise businesses throughout the U.S. that were known to have purchased wines for resale. Of the 152 wine trade respondents that were queried about how often they make a decision to purchase wine based on where it was produced, $43 \%$ indicated they always, or very often do so. These respondents became the target group of this study. Moreover, $81 \%$ of all the wine trade respondents indicated a wine's place-of-origin influenced their purchasing decision at least somewhat often as indicated in Table 1.

Table 1: Wine Trade Target and Non-Target Grouping.

\begin{tabular}{|c|c|c|c|}
\hline $\begin{array}{l}\text { How often do you: make a decision to } \\
\text { purchase one wine versus another based } \\
\text { on where it was produced? }\end{array}$ & $\begin{array}{l}\text { Total } \\
\mathrm{N}=152\end{array}$ & Percent & Grouping \\
\hline Always & 19 & $12.5 \%$ & \multirow{2}{*}{ Target Group $(\mathrm{N}=66$} \\
\hline Very Often & 47 & $30.9 \%$ & \\
\hline Somewhat Often & 57 & $37.5 \%$ & \multirow{3}{*}{$\begin{array}{l}\text { Non-Target Group } \\
\quad(\mathrm{N}=86)\end{array}$} \\
\hline Not Very Often & 24 & $15.8 \%$ & \\
\hline Never & 5 & $3.3 \%$ & \\
\hline
\end{tabular}

\section{BUSINESS CATEGORIES}

Representative samples from both on-premise and off-premise businesses were included when the wine trade survey was designed. Six of the retail wine business types were categorized as on-premise sales outlets, while four were categorized as off-premise business types. Of the ten wine trade business categories asked to participate in the survey, $71 \%$ of the respondents specified they were retail on-premise sales outlets, while $29 \%$ indicated they were off-premise business types. The proportion of each business type identified by both the target and non-target groups was very similar. The one significant difference between the two groups occurred in the retail wine shop category and highlighted in Table 2 . While $36 \%$ of the non-target respondents indicated they were a Retail wine shop, only $21 \%$ of the target group retail wine shops consider place-of-origin an important factor influencing their decision to select wines for resale. 
Table 2: Wine Trade Business Categories.

\begin{tabular}{|c|c|c|c|c|c|c|}
\hline & Business Categories & $\begin{array}{l}\text { On/Off } \\
\text { Premise } \\
\text { Outlet }\end{array}$ & $\begin{array}{l}\text { Always; } \\
\text { Very Often } \\
(\mathrm{N}=66)\end{array}$ & $\begin{array}{c}\text { Somewhat; } \\
\text { Not Very; } \\
\text { Never } \\
(\mathrm{N}=86)\end{array}$ & $\begin{array}{c}\text { Total } \\
(\mathrm{N}=152)\end{array}$ & $\begin{array}{l}\text { Chi- } \\
\text { Square }\end{array}$ \\
\hline \multirow{10}{*}{$\begin{array}{c}\text { Which of } \\
\text { the } \\
\text { following } \\
\text { describes } \\
\text { your } \\
\text { business? }\end{array}$} & Restaurant & ON & $59.1 \%$ & $51.2 \%$ & $54.6 \%$ & 0.331 \\
\hline & Wine Bar & ON & $22.7 \%$ & $23.3 \%$ & $23.0 \%$ & 0.939 \\
\hline & Bar & ON & $15.2 \%$ & $14.0 \%$ & $14.5 \%$ & 0.835 \\
\hline & Hotel & ON & $10.6 \%$ & $10.5 \%$ & $10.5 \%$ & 0.978 \\
\hline & Social Club or Golf club & ON & $4.5 \%$ & $4.7 \%$ & $4.6 \%$ & 0.975 \\
\hline & Casino & ON & $3.0 \%$ & $3.5 \%$ & $3.3 \%$ & 0.875 \\
\hline & Retail wine shop & OFF & $21.2 \%$ & $36.0 \%$ & $29.6 \%$ & $0.047^{* *}$ \\
\hline & Retail wine, spirits shop, liquor store & OFF & $13.6 \%$ & $8.1 \%$ & $10.5 \%$ & 0.274 \\
\hline & Retail outlet groceries and alcohol & OFF & $3.0 \%$ & $3.5 \%$ & $3.3 \%$ & 0.875 \\
\hline & Retail chain store & OFF & $1.5 \%$ & - & $0.7 \%$ & 0.252 \\
\hline
\end{tabular}

${ }^{* *}$ Significant at the .05 level

\section{PURCHASING BEHAVIOR}

Every wine trade survey respondent indicated their retail business sells wine. While no significant differences were detected between the two groups that offer any of the alcoholic beverages listed in Table 3 for resale, findings did reveal that craft beer-an increasingly popular substitute for wine (Manning, 2013) — is offered by $90 \%$ of the business categories represented.

Table 3: Wine Trade Beverage Types Selected for Resale.

\begin{tabular}{|c|c|c|c|c|c|}
\hline & Beverage Types & $\begin{array}{l}\text { Always; } \\
\text { Very Often } \\
(\mathrm{N}=66)\end{array}$ & $\begin{array}{l}\text { Somewhat; } \\
\text { Not Very; } \\
\text { Never } \\
(\mathrm{N}=86)\end{array}$ & $\begin{array}{c}\text { Total } \\
(\mathrm{N}=152)\end{array}$ & Chi-Square \\
\hline \multirow{7}{*}{$\begin{array}{l}\text { Which of the } \\
\text { following } \\
\text { has your } \\
\text { business } \\
\text { sold in the } \\
\text { past year? }\end{array}$} & Wine & $100.0 \%$ & $100.0 \%$ & $100.0 \%$ & * \\
\hline & Sparkling Wine/Champagne & $95.5 \%$ & $97.7 \%$ & $96.7 \%$ & 0.447 \\
\hline & Craft Beer & $93.9 \%$ & $87.2 \%$ & $90.1 \%$ & 0.168 \\
\hline & Beer & $84.8 \%$ & $74.4 \%$ & $78.9 \%$ & 0.118 \\
\hline & Spirits & $72.7 \%$ & $67.4 \%$ & $69.7 \%$ & 0.482 \\
\hline & Craft Spirits & $71.2 \%$ & $67.4 \%$ & $69.1 \%$ & 0.618 \\
\hline & None of the above & $1.5 \%$ & - & $0.7 \%$ & 0.252 \\
\hline
\end{tabular}

*No statistics computed: "Which of the following has your business sold in the past year?" is a constant.

Of the 152 wine trade respondents surveyed, almost all of them specified they also sell the seven wine varieties, the sparkling wine category, and the three generic wine blends listed in

Table 4. According to the results highlighted in Table 4, those that pay less attention to place-oforigin are more likely to purchase Sauvignon Blanc for resale. Conversely, those that do consider place-of-origin an important factor in their purchasing decisions are less likely to offer Sauvignon Blanc for resale at their retail wine businesses. 
Table 4: Wine Trade Varietals and Blends Selected for Resale.

\begin{tabular}{|c|c|c|c|c|c|}
\hline & Wine Varietals and Blends & $\begin{array}{l}\text { Always; } \\
\text { Very Often } \\
(\mathrm{N}=66)\end{array}$ & $\begin{array}{l}\text { Somewhat; } \\
\text { Not Very; } \\
\text { Never } \\
(\mathrm{N}=86)\end{array}$ & $\begin{array}{c}\text { Total } \\
(\mathrm{N}=152)\end{array}$ & Chi-Square \\
\hline \multirow{11}{*}{$\begin{array}{l}\text { Which of the } \\
\text { following } \\
\text { varietals or } \\
\text { blends have } \\
\text { you } \\
\text { purchased in } \\
\text { the past } \\
\text { year? } \\
\text { Choose all } \\
\text { that apply. }\end{array}$} & Cabernet Sauvignon & $98.5 \%$ & $100.0 \%$ & $99.3 \%$ & 0.252 \\
\hline & Chardonnay & $98.5 \%$ & $100.0 \%$ & $99.3 \%$ & 0.252 \\
\hline & Merlot & $97.0 \%$ & $98.8 \%$ & $98.0 \%$ & 0.412 \\
\hline & Pinot Grigio & $95.5 \%$ & $97.7 \%$ & $96.7 \%$ & 0.447 \\
\hline & Pinot Noir & $95.5 \%$ & $98.8 \%$ & $97.4 \%$ & 0.197 \\
\hline & Sauvignon Blanc & $95.5 \%$ & $100.0 \%$ & $98.0 \%$ & $0.046^{\star *}$ \\
\hline & Shiraz/Syrah & $97.0 \%$ & $98.8 \%$ & $98.0 \%$ & 0.412 \\
\hline & Sparkling Wine/Champagne & $97.0 \%$ & $97.7 \%$ & $97.4 \%$ & 0.788 \\
\hline & Rhone Blend & $97.0 \%$ & $97.7 \%$ & $97.4 \%$ & 0.788 \\
\hline & Red Blend & $95.5 \%$ & $98.8 \%$ & $97.4 \%$ & 0.197 \\
\hline & White Blend & $97.0 \%$ & $97.7 \%$ & $97.4 \%$ & 0.788 \\
\hline
\end{tabular}

${ }^{* *}$ Significant at the .05 level

The survey results also revealed that the wine buyers who always, or very often make purchasing decisions based on wine region were less likely to buy from Napa Valley and Sonoma County (not an AVA) as indicated in Table 5. However, a very high percentage of all the wine trade buyers do select wines from both of these well-known northern California wine regions.

Table 5: Wine Trade Purchases by Region.

\begin{tabular}{|c|c|c|c|c|c|}
\hline & Wine Regions & $\begin{array}{l}\text { Always; Very } \\
\text { Often }(N=66)\end{array}$ & $\begin{array}{l}\text { Somewhat; } \\
\text { Not Very; } \\
\text { Never } \\
(\mathrm{N}=86)\end{array}$ & $\begin{array}{c}\text { Total } \\
(\mathrm{N}=152)\end{array}$ & Chi-Square \\
\hline \multirow{9}{*}{$\begin{array}{l}\text { Wine } \\
\text { purchases in } \\
\text { the past } \\
\text { year came } \\
\text { from which } \\
\text { wine } \\
\text { growing } \\
\text { regions? }\end{array}$} & Sonoma County & $90.9 \%$ & $98.8 \%$ & $95.4 \%$ & $0.021^{* *}$ \\
\hline & Napa Valley & $89.4 \%$ & $98.8 \%$ & $94.7 \%$ & $0.010^{*}$ \\
\hline & Paso Robles & $93.9 \%$ & $90.7 \%$ & $92.1 \%$ & 0.463 \\
\hline & Central Coast & $83.3 \%$ & $91.9 \%$ & $88.2 \%$ & 0.107 \\
\hline & Santa Rita Hills & $83.3 \%$ & $91.9 \%$ & $88.2 \%$ & 0.107 \\
\hline & Outside US & $86.4 \%$ & $86.0 \%$ & $86.2 \%$ & 0.955 \\
\hline & Edna Valley & $65.2 \%$ & $66.3 \%$ & $65.8 \%$ & 0.885 \\
\hline & Arroyo Grande Valley & $63.6 \%$ & $62.8 \%$ & $63.2 \%$ & 0.915 \\
\hline & None of the above & $4.5 \%$ & $3.5 \%$ & $3.9 \%$ & 0.740 \\
\hline
\end{tabular}

10 level

${ }^{* *}$ Significant at the .05 level

\section{ATTITUDES TOWARD WINE REGIONS}

To determine how familiar the total wine trade sample was with the seven listed wine grape growing regions, they were asked to indicate their familiarity using a 5-point rating scale where 5 = Extremely Familiar; 4 = Very Familiar; 3 = Somewhat Familiar; 2 = Not Very Familiar; and $1=$ Not Familiar at All. The wine regions were sorted in descending order by their mean rating, and a paired sample t-test was performed to check for significant differences between the listed regions for the entire sample as shown in Table 6. Findings indicate the wine 
trade rated Napa Valley more familiar than Sonoma County. They also rated Sonoma County as being more familiar than the Central Coast. The trade was more acquainted with the Central Coast than they were with Santa Rita Hills, and they were more familiar with Santa Rita Hills than they were with Paso Robles. The wine trade showed they were more acquainted with Paso Robles than they were with Edna Valley, and finally, Edna Valley was rated more familiar to the wine trade than Arroyo Grande Valley was.

Table 6: Rated Familiarity Paired Sample T-Test.

\begin{tabular}{|c|c|c|c|}
\hline & Wine Regions & $\begin{array}{c}\text { Total } \\
\text { Means } \\
(\mathrm{N}=152)\end{array}$ & P-Value $^{\wedge}$ \\
\hline \multirow{7}{*}{$\begin{array}{l}\text { How familiar } \\
\text { are you with } \\
\text { the following } \\
\text { wine grape } \\
\text { growing } \\
\text { regions? }\end{array}$} & Napa Valley & 4.79 & - \\
\hline & Sonoma County & 4.75 & $0.000^{* *}$ \\
\hline & Central Coast & 4.58 & $0.000^{* *}$ \\
\hline & Santa Rita Hills & 4.37 & $0.023^{* *}$ \\
\hline & Paso Robles & 4.49 & $0.001^{* *}$ \\
\hline & Edna Valley & 4.10 & $0.000^{* *}$ \\
\hline & Arroyo Grande Valley & 3.98 & $0.035^{* *}$ \\
\hline \multicolumn{4}{|c|}{$\begin{array}{l}\text { (5 = Extremely Familiar; } 4 \text { = Very Familiar; } 3 \text { = Somewhat Familiar; } 2 \text { = Not Very } \\
\text { Familiar; } 1 \text { = Not Familiar at all) } \\
\text { ^Paired Sample t-test } \\
\text { **Significant at the } .05 \text { level }\end{array}$} \\
\hline
\end{tabular}

Seven geographic areas were examined to understand how familiar the wine trade was with each region, as well as its perceived wine quality. Respondents were asked how familiar they were with seven listed wine regions. Answers consisted of a 5-point scale where $5=$ Extremely Familiar; 4 = Very Familiar; 3 = Somewhat Familiar; 2 = Not Very Familiar; and $1=$ Not Familiar at All, from which mean ratings were determined. Napa Valley, Sonoma County and the Central Coast were rated the most familiar by all respondents as displayed in Table 7. Those that make purchases for resale based on winegrowing region were at least somewhat, to very familiar with all seven of the areas listed. However, the target group buyers indicated these three regions were significantly more familiar to them than the non-target group: 1) Central Coast; 2) Paso Robles; and 3) Arroyo Grande Valley. 
Table 7: Wine Trade Rated Familiarity by Region.

\begin{tabular}{|c|c|c|c|c|c|}
\hline \multicolumn{2}{|c|}{ Table 7: Wine Trade Rated Familiarity by Region. } & \multicolumn{2}{|c|}{ Mean } & \multirow[b]{2}{*}{$\begin{array}{c}\text { Total } \\
\text { Means } \\
(\mathrm{N}=152)\end{array}$} & \multirow[b]{2}{*}{ P-Value ${ }^{\wedge}$} \\
\hline & Wine Regions & $\begin{array}{l}\text { Always; } \\
\text { Very Often } \\
(\mathrm{N}=66)\end{array}$ & $\begin{array}{c}\text { Somewhat; } \\
\text { Not Very; } \\
\text { Never } \\
(\mathrm{N}=86)\end{array}$ & & \\
\hline \multirow{7}{*}{$\begin{array}{l}\text { How familiar are you } \\
\text { with the following } \\
\text { wine grape growing } \\
\text { regions? }\end{array}$} & Napa Valley & 4.83 & 4.76 & 4.79 & 0.340 \\
\hline & Sonoma County & 4.80 & 4.71 & 4.75 & 0.187 \\
\hline & Central Coast & 4.74 & 4.46 & 4.58 & $0.002^{* *}$ \\
\hline & Santa Rita Hills & 4.45 & 4.31 & 4.37 & 0.246 \\
\hline & Paso Robles & 4.25 & 4.00 & 4.49 & $0.046^{* *}$ \\
\hline & Edna Valley & 4.18 & 4.01 & 4.10 & 0.243 \\
\hline & Arroyo Grande Valley & 4.14 & 3.85 & 3.98 & $0.078^{*}$ \\
\hline
\end{tabular}

(5 = Extremely Familiar; 4 = Very Familiar; 3 = Somewhat Familiar; 2 = Not Very Familiar; 1 = Not Familiar at all)

^Independent Sample t-test

${ }^{*}$ Significant at the .10 level

${ }^{* *}$ Significant at the .05 level

To determine how the total trade sample perceived the quality of wines from the seven wine grape growing regions, a 5-point rating scale was used where $5=$ Excellent Quality; $4=$ Very Good Quality; 3 = Somewhat Good Quality; 2 = Not Very Good Quality; and 1 = Poor Quality. The wine regions were sorted in descending order by their mean rating, and a paired sample t-test was performed to check for significant differences between the listed regions for the entire trade sample as shown in Table 8. Findings indicate the wine trade rated wines from Napa Valley as being higher in quality than Sonoma County. However, they considered the quality of wines from Sonoma County and Santa Rita Hills to be the same (no significant difference). The wine trade rated wines from Santa Rita Hills to be higher quality than Paso Robles wines. The trade also rated wine quality from Paso Robles higher than the Central Coast, and they considered the quality of wines from the Central Coast and Edna Valley to be the same. Lastly, the trade also deemed the quality of wines from Edna Valley and Arroyo Grande Valley to be equal.

Table 8: Rated Quality Paired Sample T-Test.

\begin{tabular}{|c|c|c|c|}
\hline & Wine Regions & $\begin{array}{l}\text { Total Means } \\
\qquad(\mathrm{N}=152)\end{array}$ & P-Value $^{\wedge}$ \\
\hline \multirow{7}{*}{$\begin{array}{l}\text { How would } \\
\text { you rate the } \\
\text { quality of } \\
\text { wine } \\
\text { produced in } \\
\text { the following } \\
\text { regions? }\end{array}$} & Napa Valley & 4.59 & - \\
\hline & Sonoma County & 4.48 & $0.004^{* *}$ \\
\hline & Santa Rita Hills & 4.43 & 0.487 \\
\hline & Paso Robles & 4.10 & $0.000^{* *}$ \\
\hline & Central Coast & 3.96 & $0.036^{* *}$ \\
\hline & Edna Valley & 3.95 & 1.000 \\
\hline & Arroyo Grande Valley & 3.95 & 0.885 \\
\hline \multicolumn{4}{|c|}{$\begin{array}{l}\text { (5 = Excellent Quality; } 4 \text { = Very Good Quality; } 3 \text { = Somewhat Good Quality; } \\
2 \text { = Not Very Good Quality; } 1 \text { = Poor Quality) } \\
\text { ^Paired Sample t-test } \\
\text { **Significant at the } .05 \text { level }\end{array}$} \\
\hline
\end{tabular}


Wine trade respondents were asked to rate the wine quality from the same seven wine regions that were listed for familiarity. Answers to this question consisted of a 5-point rating scale where 5 = Excellent Quality; 4 = Very Good Quality; 3 = Somewhat Good Quality; 2 = Not Very Good Quality; and 1 = Poor Quality, from which mean ratings were determined and displayed in Table 9. The perceived quality ratings of the seven grape growing regions listed were considered at least very good quality by all respondents (mean range of 4.59 to 3.95). However, the wine trade buyers that always, or very often make purchasing decisions based on place-of-origin rated the wines from the following regions as being significantly higher in quality than the non-target group did: 1) Napa Valley; 2) Sonoma County; and 3) Paso Robles.

Table 9: Wine Trade Rated Quality by Region.

\begin{tabular}{|c|c|c|c|c|c|}
\hline \multicolumn{2}{|c|}{ Table 9: Wine Trade Rated Quality by Region. } & \multicolumn{2}{|c|}{ Mean } & \multirow[b]{2}{*}{$\begin{array}{c}\text { Total } \\
\text { Means } \\
(\mathrm{N}=152)\end{array}$} & \multirow[b]{2}{*}{$\mathrm{P}^{-V_{\text {Value }}}$} \\
\hline & Wine Regions & $\begin{array}{l}\text { Always; } \\
\text { Very Often } \\
(\mathrm{N}=66)\end{array}$ & $\begin{array}{l}\text { Somewhat; } \\
\text { Not Very; } \\
\text { Never } \\
(\mathrm{N}=86)\end{array}$ & & \\
\hline \multirow{7}{*}{$\begin{array}{l}\text { How would you rate } \\
\text { the quality of wine } \\
\text { produced in the } \\
\text { following regions? }\end{array}$} & Napa Valley & 4.68 & 4.52 & 4.59 & $0.067^{*}$ \\
\hline & Sonoma County & 4.62 & 4.38 & 4.48 & $0.015^{* *}$ \\
\hline & Santa Rita Hills & 4.48 & 4.40 & 4.43 & 0.474 \\
\hline & Paso Robles & 4.25 & 4.00 & 4.10 & $0.046^{* *}$ \\
\hline & Central Coast & 4.06 & 3.89 & 3.96 & 0.157 \\
\hline & Edna Valley & 4.02 & 3.89 & 3.95 & 0.256 \\
\hline & Arroyo Grande Valley & 4.03 & 3.90 & 3.95 & 0.219 \\
\hline
\end{tabular}

\section{ATTITUDES TOWARD WINE CHARACTERISTICS}

Rating the eight desirability factors of the trade sample consisted of using a 5-point scale where 5 = Extremely Desirable; 4 = Very Desirable; 3 = Somewhat Desirable; 2 = Not Very Desirable; and $1=$ Not Desirable at All. These attributes were sorted in descending order by their mean rating, and a paired sample t-test was performed to test for significant differences between the listed features for the entire sample as shown in Table 10. Findings show the wine trade rated Premium quality product higher than Grapes from a respected wine grape growing region.

Furthermore, Grapes from a respected wine grape growing region was rated more desirable than From a well known AVA. This could suggest the wine trade buyers may be uncertain about the term AVA, and more familiar with overarching wine regions. Sustainably produced was less 
desirable than From a well known AVA. However, Sustainably produced, and Produced from cool climate grapes, were equally desirable (no significant difference). Produced from cool climate grapes was perceived the same as Produced in California, while Produced in California was rated higher than High Wine Spectator Rating. Lastly, High Wine Spectator Rating and High Robert Parker Rating were considered the same and considered equally desirable by the wine trade.

Table 10: Rated Desirability Features Paired Sample T-Test.

\begin{tabular}{|c|c|c|c|}
\hline & Desirability Features & $\begin{array}{c}\text { Total } \\
\text { Means } \\
(\mathrm{N}=152)\end{array}$ & P-Value ${ }^{\wedge}$ \\
\hline \multirow{8}{*}{$\begin{array}{l}\text { Indicate the } \\
\text { desirability of each } \\
\text { feature when you } \\
\text { purchase wine for } \\
\text { your outlet. }\end{array}$} & Premium quality product & 4.77 & - \\
\hline & $\begin{array}{l}\text { Grapes from a respected wine grape } \\
\text { growing region }\end{array}$ & 4.14 & $0.000 * *$ \\
\hline & From a well-known AVA & 3.66 & $0.000 * *$ \\
\hline & Sustainably produced & 3.49 & $0.067^{*}$ \\
\hline & Produced from cool climate grapes & 3.36 & 0.132 \\
\hline & Produced in California & 3.34 & 0.780 \\
\hline & High Wine Spectator Rating & 2.99 & $0.000^{* *}$ \\
\hline & High Robert Parker Rating & 2.95 & 0.298 \\
\hline \multicolumn{4}{|c|}{$\begin{array}{l}\text { (5 = Extremely Desirable; } 4 \text { = Very Desirable; } 3 \text { = Somewhat Desirable; } 2 \text { = Not Very Desirable; } 1 \text { = Not } \\
\text { Desirable at all) } \\
\text { ^Paired Sample t-test } \\
\text { *Significant at the } .10 \text { level } \\
\text { ** Sianificant at the } 05 \text { level }\end{array}$} \\
\hline
\end{tabular}

The wine trade buyers were asked to rate eight desirability features influencing their decision to purchase wines for resale. Answers to this question consisted of a 5-point rating scale where 5 = Extremely Desirable; $4=$ Very Desirable; $3=$ Somewhat Desirable $; 2=$ Not Very Desirable; and 1 = Not Desirable at All, from which mean ratings were derived and displayed in Table 11. The total sample of respondents disclosed that the most desirable wine features affecting their purchasing decisions were: 1) Premium quality product; and 2) Grapes from a respected wine grape growing region. However, the non-target group rated wines From a wellknown AVA as only a somewhat desirable trait (mean $=3.42$ ). Of those wine trade buyers making purchasing decisions based on where the wine is produced, the following features were considered to be significantly more desirable to them than the non-target group: 1) Grapes from a respected wine grape growing region; 2) From a well-known AVA; and 3) Produced in California. These findings add convergent validity to the data since the target group makes 
decisions based on wine region and values it higher than those less inclined to buy wines according to place-of-origin. Results also revealed that appraisals from either wine industry periodicals or celebrity wine reviewers were rated as only somewhat desirable by both groups (means of 2.95 and 2.99). Therefore, place-of-origin impacts the purchasing decisions of the wine trade sample more than expert ratings do.

Table 11: Wine Trade Rated Desirability Features.

Table 11: Wine Trade Rated Desirability Features.
\begin{tabular}{|c|l|c|c|c|c|}
\hline \multirow{2}{*}{} & \multicolumn{1}{|c|}{ Desirability Features } & $\begin{array}{c}\text { Always; } \\
\text { Very Often } \\
(\mathrm{N}=66)\end{array}$ & $\begin{array}{c}\text { Somewhat; } \\
\text { Not Very; } \\
\text { Never } \\
(\mathrm{N}=86)\end{array}$ & $\begin{array}{c}\text { Total } \\
\text { Means } \\
(\mathrm{N}=152)\end{array}$ & P-Value $^{\wedge}$ \\
\hline \multirow{3}{*}{$\begin{array}{c}\text { Indicate the } \\
\text { desirability of } \\
\text { each feature } \\
\begin{array}{c}\text { when you } \\
\text { purchase } \\
\text { wine for your } \\
\text { outlet. }\end{array}\end{array}$} & $\begin{array}{l}\text { Grapes from a respected wine grape } \\
\text { growing region }\end{array}$ & 4.83 & 4.72 & 4.77 & 0.197 \\
\cline { 2 - 7 } & From a well-known AVA & 4.32 & 4.01 & 4.14 & $0.008^{* *}$ \\
\cline { 2 - 7 } & Sustainably produced & 3.92 & 3.42 & 3.66 & $0.000^{* *}$ \\
\cline { 2 - 7 } & Produced from cool climate grapes & 3.40 & 3.55 & 3.49 & 0.339 \\
\cline { 2 - 7 } & High Wine Spectator Rating & 3.44 & 3.27 & 3.36 & 0.271 \\
\cline { 2 - 7 } & High Robert Parker Rating & 3.58 & 3.14 & 3.34 & $0.001^{* *}$ \\
\hline
\end{tabular}

(5 = Extremely Desirable; 4 = Very Desirable; 3 = Somewhat Desirable; 2 = Not Very Desirable; 1 = Not Desirable at all) Independent Sample t-test

${ }^{* *}$ Significant at the .05 level 


\section{DATA COLLECTION: CONSUMER SURVEY}

The purchasing behavior studies previously cited in the Literature Review mainly addressed consumer attitudes and how awareness of regional wine reputation influences their buying habits. Only one of the studies (Rickard, et al., 2015) mentioned how it was inspired by California wine events linking up-and-coming domestic wine regions to French counterparts utilizing a phenomenon they called reputation tapping. The primary focus of the Rickard, et al. (2015) study was to see if there was a measurable influence associating Old World wine region quality with lesser-known New World AVAs. Since so much attention has already been given to the buying motives associated with two of the most celebrated northern California wine regions, Napa Valley and Sonoma County, this study included less prominent central coast winegrowing areas to determine how they affected consumer buying decisions. Five AVAs located in San Luis Obispo County, together with one AVA in Santa Barbara County, were included in this study to examine how consumer familiarity and quality perceptions influenced their purchasing behavior.

To achieve the research objectives, a wine consumer survey consisting of 31 questions

(see Appendix B) was conducted outside selected grocery stores in San Luis Obispo County using the personal interview method during the months of October 2014, and February 2015. The questionnaire was originally developed by students enrolled in the Wine and Viticulture Department at Cal Poly, San Luis Obispo, and used to collect primary data from 302 respondents. This was a convenience sample. As with the wine trade survey, the consumer survey instrument was originally designed to determine the level of interest in a proposed new coastal AVA within San Luis Obispo County.

\section{CONSUMER DEMOGRAPHICS}

Examination of the wine consumer demographics were compared against similar data provided by the following MRI+ MediaMark report: Fall 2013 Product Report; Alcoholic 
Beverages; Any Wines. This was done to determine how similar the convenience sample was to the typical wine consumer. The consumer demographics of the sample that participated in this study were similar to the MRI+ statistics of domestic wine consumers, although there was a higher proportion of younger respondents in the sample.

Table 12 shows how the gender proportion of the 302 respondents in the convenience sample differed slightly from the national MRI+ breakdown of female and male that were reported to have had consumed any type of wine in the preceding six months.

Table 12: Consumer Respondents by Gender.

\begin{tabular}{|c|c|c|c|}
\hline & & MRI+ & $\begin{array}{c}\text { Survey Total } \\
(\mathrm{N}=302)\end{array}$ \\
\hline \multirow{2}{*}{ Are you? } & Female & $60.2 \%$ & $53.3 \%$ \\
\cline { 2 - 4 } & Male & $39.8 \%$ & $46.7 \%$ \\
\hline
\end{tabular}

Survey results show that $80 \%$ of the respondents do not have minor children in the household, while $48 \%$ indicated they were married as displayed in Tables 13 and 14. This is in contrast to the MRI+ statistical data that reported 55\% have children under the age of 18 living at home, and $60 \%$ of domestic wine consumers were married.

Table 13: Consumer Respondents with Children in Household.

\begin{tabular}{|c|c|c|c|}
\hline & & MRI+ & $\begin{array}{c}\text { Survey Total } \\
(\mathrm{N}=302)\end{array}$ \\
\hline Do you have children under & Yes & $54.9 \%$ & $20.4 \%$ \\
\cline { 2 - 4 } the age of 18 living at home? & No & $45.1 \%$ & $79.6 \%$ \\
\hline
\end{tabular}

Table 14: Marital Status of Consumer Respondents.

\begin{tabular}{|l|l|c|c|}
\hline \multirow{3}{*}{ Are you? } & MRI+ & $\begin{array}{c}\text { Survey Total } \\
(\mathrm{N}=302)\end{array}$ \\
\hline \multirow{3}{*}{} & Married & $59.7 \%$ & $48.1 \%$ \\
\cline { 2 - 4 } & Living with a partner & $\mathrm{n} / \mathrm{a}$ & $10.4 \%$ \\
\cline { 2 - 4 } & Single & $22.8 \%$ & $39.4 \%$ \\
\cline { 2 - 4 } & Widowed & $17.5 \%$ & $2.0 \%$ \\
\hline
\end{tabular}

The wine consumer respondents between 21-27 years of age (28\%), and 45-54 years of age $(26 \%)$ made up the majority of the sample demographics as indicated in Table 15 . This differed slightly from MRI+ statistical data that reported $20 \%$ of domestic wine consumers were 
between 45-54 years old, while only $25 \%$ were between the more extensive range of 18-34 years of age.

Table 15: Age Range of Consumer Respondents.

\begin{tabular}{|c|c|c|c|}
\hline & Age Range & MRI+ & $\begin{array}{c}\text { Survey Total } \\
(\mathrm{N}=302)\end{array}$ \\
\hline \multirow{10}{*}{$\begin{array}{l}\text { How often do } \\
\text { you make a } \\
\text { decision to } \\
\text { purchase one } \\
\text { wine versus } \\
\text { another based } \\
\text { on where it was } \\
\text { produced? }\end{array}$} & 21 to 24 & $8.3 \%$ & $13.9 \%$ \\
\hline & 25 to 27 & \multirow{4}{*}{$17.0 \%$} & $13.9 \%$ \\
\hline & 28 to 29 & & $6.3 \%$ \\
\hline & 30 to 32 & & $5.0 \%$ \\
\hline & 33 to 36 & & $7.6 \%$ \\
\hline & 37 to 39 & \multirow{2}{*}{$17.7 \%$} & $3.6 \%$ \\
\hline & 40 to 44 & & $6.3 \%$ \\
\hline & 45 to 54 & $20.3 \%$ & $25.5 \%$ \\
\hline & 55 to 64 & $18.0 \%$ & $8.6 \%$ \\
\hline & $65+$ & $18.7 \%$ & $9.3 \%$ \\
\hline
\end{tabular}

Results from the survey also revealed that $57 \%$ of the total consumer respondents in this study earned a college degree as indicated in Table 16. This is higher than the national MRI+ statistical data which shows that only $42 \%$ of domestic wine consumers graduated from college.

Table 16: Education Level of Consumer Respondents.

\begin{tabular}{|c|l|c|c|}
\hline & & $\mathrm{MRI}$ & $\begin{array}{c}\text { Survey Total } \\
(\mathrm{N}=302)\end{array}$ \\
\hline \multirow{3}{*}{$\begin{array}{c}\text { Please tell me the } \\
\text { level of education } \\
\text { you have }\end{array}$} & Grade School or Less & $\mathrm{n} / \mathrm{a}$ & $0.3 \%$ \\
\cline { 2 - 4 } $\begin{array}{c}\text { completed. (Circle } \\
\text { only one) }\end{array}$ & Some High School & $\mathrm{n} / \mathrm{a}$ & $1.3 \%$ \\
\cline { 2 - 4 } & High School Graduate & $21.2 \%$ & $6.0 \%$ \\
\cline { 2 - 4 } & Some College & $17.8 \%$ & $22.1 \%$ \\
\cline { 2 - 4 } & College Graduate & $42.4 \%$ & $56.9 \%$ \\
\cline { 2 - 4 } & Post Graduate Work & $18.3 \%$ & $13.4 \%$ \\
\hline
\end{tabular}

Sixty-nine percent of the wine consumer respondents indicated they were employed full time as shown in Table 17. This is very similar to the MRI+ statistical data that reported $66 \%$ of domestic wine consumers were included in the five occupation categories listed in the report.

Table 17: Employment Status of Consumer Respondents.

\begin{tabular}{|c|l|c|c|}
\hline & MRI+ & $\begin{array}{c}\text { Survey } \\
\text { Total } \\
(\mathrm{N}=302)\end{array}$ \\
\hline \multirow{2}{*}{$\begin{array}{c}\text { Are you } \\
\text { employed? }\end{array}$} & Employed, Full Time & $66.1 \%$ & $68.7 \%$ \\
\cline { 2 - 4 } & Employed, Part Time & $\mathrm{n} / \mathrm{a}$ & $14.1 \%$ \\
\cline { 2 - 4 } & Not Employed or Retired & $\mathrm{n} / \mathrm{a}$ & $17.2 \%$ \\
\hline
\end{tabular}

Thirty-five percent of the total wine consumer respondents indicated they earn between $\$ 75,000-150,000+$ annually as shown in Table 18 . These findings were in contrast to the national MRI+ statistical data that disclosed $54 \%$ of domestic wine consumer households earn the same. 
Table 18: Income Range of Consumer Respondents.

\begin{tabular}{|c|c|c|c|}
\hline & & $\mathrm{MRI}+$ & $\begin{array}{c}\text { Survey Total } \\
(\mathrm{N}=302)\end{array}$ \\
\hline \multirow{10}{*}{$\begin{array}{l}\text { Which of } \\
\text { the } \\
\text { following } \\
\text { ranges } \\
\text { describes } \\
\text { your } \\
\text { household } \\
\text { income } \\
\text { before } \\
\text { taxes? }\end{array}$} & Under $\$ 20,000$ & $7.9 \%$ & $10.4 \%$ \\
\hline & $\$ 20,000$ to $\$ 24,999$ & \multirow[b]{2}{*}{$6.6 \%$} & $3.8 \%$ \\
\hline & $\$ 25,000$ to $\$ 29,999$ & & $6.2 \%$ \\
\hline & $\$ 30,000$ to $\$ 34,999$ & \multirow{2}{*}{$7.2 \%$} & $5.0 \%$ \\
\hline & $\$ 35,000$ to $\$ 39,999$ & & $4.2 \%$ \\
\hline & $\$ 40,000$ to $\$ 49,999$ & $6.8 \%$ & $7.7 \%$ \\
\hline & $\$ 50,000$ to $\$ 59,999$ & $7.0 \%$ & $10.8 \%$ \\
\hline & $\$ 60,000$ to $\$ 74,999$ & $10.3 \%$ & $16.9 \%$ \\
\hline & $\$ 75,000$ to $\$ 149,999$ & $37.1 \%$ & $20.0 \%$ \\
\hline & $\$ 150,000$ or more & $17.1 \%$ & $15.0 \%$ \\
\hline
\end{tabular}

As with the trade sample contacts, the principal question to this part of the study asked the 302 wine consumer respondents how often they make purchasing decisions based on a wine's provenance. Do specific California wine regions have any influence on the buying habits of the typical wine consumer? Options consisted of a 5-point rating scale as follows: $5=$ Always; $4=$ Very Often; 3 = Somewhat Often; 2 = Not Very Often; and 1 = Never. Answers to this question were used to split the respondents into two groups. Those wine consumers that indicated they always, or very often make purchasing decisions based on where the wine was produced became the target group of this portion of the study. This group is aware of a wine's perceived value, and/or quality when it is associated with a designated geographic locale. The remaining subset, or non-target group, consisted of respondents that indicated they somewhat often, not very often, or never consider place-of-origin an important factor when selecting wines for purchase.

To also help identify how important place-of-origin is to the purchase decision process, the respondents were then asked how often they read the wine bottle label to learn where the wine was produced. Options also consisted of the same 5-point rating scale as follows: $5=$ Always; 4 $=$ Very Often; 3 = Somewhat Often; $2=$ Not Very Often; and $1=$ Never. Branding efforts that featured place-of-origin were explored by Bruwer and Johnson (2010), with one caveat; the overwhelming number of wine labels can be intimidating for the casual wine consumer when there are so many brands to choose from. 
A combination of queries addressing consumer purchasing behaviors was included in the next section of the survey. The respondents were asked to indicate what categories of alcoholic beverages they had purchased the previous year. Five customary categories were provided to select from, as well as the general option None of the above. Respondents were asked to identify which of the ten popular wine varietals and blends listed they had purchased during the preceding year. Included was the additional choice I don't know which varietals or blends I purchase. The respondents were then asked which wine grape growing regions the wines they had purchased during the previous year originated from. A choice of nine options was provided to identify which regions were recognizable and if they had any influence on the buying habits of the respondents. The list of grape growing areas included the two premier northern California regions, one renowned AVA located in Santa Barbara County, the very extensive central coast region, the Sierra Foothills AVA, and four AVAs located within San Luis Obispo County. Choosing these areas was twofold: the first was to determine if there were any differences between the influence northern California wine regions had on wine consumer purchasing behavior when contrasted with the local up-and-coming regions of the central coast and San Luis Obispo County. The second reason was simply to see if the consumer responses differed from those of the wine trade. However, no useful comparisons can be made between the answers the wine consumers and wine trade provided since they were treated separately for the purposes of this study. The following choices were likewise included to further define purchasing behavior: None of the above; Other; and I DO NOT KNOW which grape growing regions my wine comes from.

Continuing with wine consumer purchasing behaviors, the respondents were asked the following questions: 1) Approximately how many bottles of wine do you typically buy per month at a retail outlet; 2) Approximately how much do you spend on wine in a typical month at a retail outlet; 3) Approximately how many glasses and/or bottles of wine do you typically buy per 
month at a restaurant or bar; and 4) What price range do the majority of your $750 \mathrm{ml}$ wine bottle purchases at a retail outlet fall into (a list of six price ranges was offered).

The next set of questions addressed consumer attitudes influencing the selection process when wines were purchased. The consumer survey included a list of eight California AVAs, and one northern county, to determine familiarity and gauge perceived wine quality. Johnson's (2011) paper looked at how the Napa Valley has been effectively marketed and how its quality reputation carries over to other products besides wine. Atkin and Newton's (2012) study, along with Johnson and Bruwer's (2007), mentioned how important it was to preserve the overarching regional brand identity when smaller AVAs were being promoted. Respondents were asked to rate how familiar they were with any of the nine listed wine grape growing regions using a 5point rating scale where $5=$ Extremely Familiar; $4=$ Very Familiar; $3=$ Somewhat Familiar; $2=$ Not Very Familiar; and $1=$ Not Familiar at All. The wine consumers were also asked to rate the quality of wines produced in those same nine wine grape growing regions, again using a similar 5-point rating scale where 5 = Excellent Quality; 4 = Very Good Quality; 3 = Somewhat Good Quality; 2 = Not Very Good Quality; and 1 = Poor Quality. Answers to these questions would be used to determine if the three larger wine regions, Napa Valley, Sonoma County and Paso Robles, had more of an influence on consumer purchasing decisions than the six smaller AVAs did. Respondents were also asked to indicate the desirability of six features when they purchase wines for consumption. Replies to this question consisted of a 5-point rating scale as follows: $5=$ Extremely Desirable; 4 = Very Desirable; 3 = Somewhat Desirable; 2 = Not Very Desirable; and $1=$ Not Desirable at All.

The concluding series of survey questions were used to classify the sample wine consumer demographics. The respondents were asked to provide answers to the following inquiries: 1) Age range; 2) Gender; 3) Relationship status; 4) Education level; 5) Employment status; 6) Income range; 7) Children in household; and 8) Sources of wine information. 


\section{METHODOLOGY FOR CONSUMER SURVEY}

The questionnaire responses were entered into the SPSS program (IBM SPSS Statistics) and analyzed to determine if there were significant differences between the two groups of wine consumers based on demographics, purchasing behaviors and attitudes. The target group consisted of respondents that indicated they always, or very often make purchasing decisions based on a wine's provenance, while the non-target group indicated they somewhat often, not very often, or never consider place-of-origin an important factor when selecting wines for consumption.

Chi-Square tests were used for all nominal and ordinal variables comparisons, and independent sample t-tests were used for all ratio and interval variables comparisons. If the PValue $\leq 0.10$ for any of the tests, the null hypothesis asserting there was no statistically significant difference between the target and non-target groups that make decisions to purchase one wine versus another based on place-of-origin, was rejected ${ }^{3}$. Chi-Square tests were used to identify any significant differences between the target and non-target wine consumer groups when comparing: 1) the purchasing behavior of the two groups that indicated which of the five types of alcoholic beverages listed they had bought during the preceding year; 2) the principal price range of $750 \mathrm{ml}$ wine bottles they had purchased; 3) the purchasing behavior of the respondents that selected any of the ten wine varietals and blends listed; 4) the purchasing behavior of the two groups that indicated which of the nine places-of-origin the wines they selected came from; and 5) the eight wine consumer demographic categories.

Independent sample t-tests were used to examine any significant differences between the means of the wine consumer target and non-target groups for all interval and ratio variables.

\footnotetext{
${ }^{3}$ Chi-Square test, Independent sample t-test and Paired sample t-test results are highlighted in the following manner: P-Values $\leq 0.10$, and $>0.05$, will be displayed with a single asterisk $(*)$ indicating a $90 \%$ confidence level between survey responses. Values $\leq 0.05$ will be displayed with a double asterisk $(* *)$ indicating a $95 \%$ confidence level between survey responses.
} 
These independent sample t-tests compared the attitudes of the two wine consumer groups when looking at the following: 1) how they rated the familiarity of the nine listed grape growing regions; 2) how they rated the quality of the same nine listed grape growing regions; 3) how they rated the list of six wine desirability features; 4) the number of monthly wine bottle purchases; 5) the average wine bottle purchase price; and 6) the number of bottles and/or glasses of wine purchased monthly.

Paired sample t-tests were employed to determine if there were significant differences between the six wine desirability features the total wine consumer sample rated, and if there were significant differences between the nine selected grape growing regions that the total wine consumer sample rated for both familiarity and quality. If the P-Value $\leq 0.10$, then the null hypothesis stating there were no statistically significant differences between the compared elements was rejected. 


\section{RESULTS OF CONSUMER SURVEY}

During the months of October 2014, and February 2015, a wine consumer survey was conducted outside selected grocery stores in San Luis Obispo County using the personal interview method. Primary data was collected from 302 wine consumer respondents willing to participate in the survey. The demographics were similar to the typical wine consumer, except slightly younger. Of the total wine consumer respondents that were asked how often they make purchasing decisions based on where the wine was produced, $38 \%$ indicated they always, or very often do so. These respondents became the target group of this portion of the study. Moreover, $69 \%$ of all wine consumer respondents specified that a wine's provenance influenced their purchasing decision at least somewhat often as displayed in Table 19. Chi-square tests were used to examine if demographics were related to the target group. Results indicated there was no relationship found. Therefore, the target group sample was demographically similar to the typical wine consumer.

Table 19: Wine Consumer Target and Non-Target Grouping.

\begin{tabular}{|l|c|c|c|}
\hline $\begin{array}{l}\text { How often do you: make a decision to } \\
\text { purchase one wine versus another based } \\
\text { on where it was produced? }\end{array}$ & $\begin{array}{c}\text { Total } \\
\mathrm{N}=302\end{array}$ & Percent & Grouping \\
\hline Always & 36 & $11.9 \%$ & \multirow{2}{*}{$\begin{array}{c}\text { Target Group } \\
\text { (N=116) }\end{array}$} \\
\hline Very often & 80 & $26.5 \%$ & \multirow{2}{*}{$\begin{array}{c}\text { Non-Target Group } \\
\text { Somewhat often }\end{array}$} \\
\cline { 1 - 3 } Not very often & 92 & $30.5 \%$ & $186)$ \\
\cline { 1 - 2 } Never & 41 & $13.5 \%$ & \\
\hline
\end{tabular}

\section{INFORMATION SOURCING BEHAVIOR}

Examining the wine label reading behavior of the consumers revealed that $90 \%$ of the target group always, or very often Read the label to learn where the wine was produced, compared to $41 \%$ of the non-target group that does likewise. These results are highlighted in Table 20. Verifying wine regions and other pertinent information found on wine labels is extremely important to the target group and validates how place-of-origin strongly influences their decision to make a wine purchase. 
Table 20: Wine Label Readers Target and Non-Target Grouping.

\begin{tabular}{|c|c|c|c|c|c|}
\hline & & $\begin{array}{l}\text { Always; } \\
\text { Very Often } \\
(\mathrm{N}=116)\end{array}$ & $\begin{array}{l}\text { Somewhat; } \\
\text { Not Very; } \\
\text { Never } \\
(\mathrm{N}=186)\end{array}$ & $\begin{array}{c}\text { Total } \\
(\mathrm{N}=302)\end{array}$ & P-Value ${ }^{\wedge}$ \\
\hline \multirow{5}{*}{$\begin{array}{l}\text { How often do you: } \\
\text { read the label of a } \\
\text { wine bottle to } \\
\text { learn where it was } \\
\text { produced? }\end{array}$} & Always & $67.2 \%$ & $16.1 \%$ & $35.8 \%$ & \multirow{5}{*}{$0.000^{* *}$} \\
\hline & Very often & $23.3 \%$ & $24.7 \%$ & $24.2 \%$ & \\
\hline & Somewhat often & $6.9 \%$ & $32.3 \%$ & $22.5 \%$ & \\
\hline & Not very often & $2.6 \%$ & $16.7 \%$ & $11.3 \%$ & \\
\hline & Never & $0.0 \%$ & $10.2 \%$ & $6.3 \%$ & \\
\hline
\end{tabular}

Despite the overabundance of printed and electronic media sources listed in Table 21,

findings from this study revealed that personal recommendations from family and friends remain the top choice for gathering wine information for all respondents. For the target group, visits to wineries, frequenting wine bars, attending wine events, and recommendations from servers and sommeliers at restaurants were rated as the next most utilized sources of wine information. These lifestyle interests confirm that the target group actively seeks out communal opportunities to learn more about wine. Likewise, these wine enthusiasts also peruse wine magazines and newsletters, view winery websites and blogs, and depend on wine club and wine trail maps to provide them with current information that influences their wine purchasing decisions.

Table 21: Wine Information Sources of Consumer Respondents.

\begin{tabular}{|c|c|c|c|c|c|}
\hline & INFORMATON SOURCES & $\begin{array}{l}\text { Always; } \\
\text { Very Often } \\
(\mathrm{N}=116)\end{array}$ & $\begin{array}{c}\text { Somewhat; } \\
\text { Not Very; } \\
\text { Never } \\
(\mathrm{N}=186)\end{array}$ & $\begin{array}{c}\text { Total } \\
(\mathrm{N}=302)\end{array}$ & Chi-Square \\
\hline \multirow{14}{*}{$\begin{array}{l}\text { Which of the } \\
\text { following do you do } \\
\text { or use regularly to } \\
\text { get information } \\
\text { about wine? } \\
\text { (Choose all that } \\
\text { apply) }\end{array}$} & Family or Friends & $72.4 \%$ & $66.1 \%$ & $68.5 \%$ & 0.253 \\
\hline & Visits to Wineries & $52.6 \%$ & $40.3 \%$ & $45.0 \%$ & $0.037^{* *}$ \\
\hline & Wine Bars & $40.5 \%$ & $24.7 \%$ & $30.8 \%$ & $0.004^{* *}$ \\
\hline & Wine Events & $39.7 \%$ & $21.0 \%$ & $28.1 \%$ & $0.000^{* *}$ \\
\hline & Servers/Sommeliers at restaurants & $34.5 \%$ & $26.3 \%$ & $29.5 \%$ & 0.131 \\
\hline & Wine magazines (Print) & $32.8 \%$ & $14.5 \%$ & $21.5 \%$ & $0.000^{* *}$ \\
\hline & Winery Websites & $31.9 \%$ & $15.6 \%$ & $21.9 \%$ & $0.001^{* *}$ \\
\hline & Food magazines (Print) & $22.4 \%$ & $23.1 \%$ & $22.8 \%$ & 0.887 \\
\hline & Facebook & $21.6 \%$ & $25.3 \%$ & $23.8 \%$ & 0.461 \\
\hline & Blogs & $19.8 \%$ & $6.5 \%$ & $11.6 \%$ & $0.000^{* *}$ \\
\hline & Winery Newsletters & $19.8 \%$ & $6.5 \%$ & $11.6 \%$ & $0.000^{* *}$ \\
\hline & Wine Spectator & $19.8 \%$ & $4.3 \%$ & $10.3 \%$ & $0.000^{* *}$ \\
\hline & Web search & $19.0 \%$ & $19.4 \%$ & $19.2 \%$ & 0.933 \\
\hline & Wine Club Information & $18.1 \%$ & $7.5 \%$ & $11.6 \%$ & $0.005^{* *}$ \\
\hline
\end{tabular}

** Significant at the .05 level 
Table 21: Wine Information Sources of Consumer Respondents (cont'd).

\begin{tabular}{|c|c|c|c|c|c|}
\hline & INFORMATION SOURCES (cont'd) & $\begin{array}{l}\text { Always; } \\
\text { Very Often } \\
(\mathrm{N}=116)\end{array}$ & $\begin{array}{c}\text { Somewhat; } \\
\text { Not Very; } \\
\text { Never } \\
(\mathrm{N}=186)\end{array}$ & $\begin{array}{c}\text { Total } \\
(\mathrm{N}=302)\end{array}$ & Chi-Square \\
\hline \multirow{13}{*}{$\begin{array}{l}\text { Which of the } \\
\text { following do you do } \\
\text { or use regularly to } \\
\text { get information } \\
\text { about wine? } \\
\text { (Choose all that } \\
\text { apply) }\end{array}$} & Sunset Magazine (Print) & $16.4 \%$ & $15.1 \%$ & $15.6 \%$ & 0.757 \\
\hline & Online Newspapers & $12.9 \%$ & $8.1 \%$ & $9.9 \%$ & 0.169 \\
\hline & Pinterest & $12.1 \%$ & $13.4 \%$ & $12.9 \%$ & 0.730 \\
\hline & Wine Trail Maps & $12.1 \%$ & $6.5 \%$ & $8.6 \%$ & $0.091^{*}$ \\
\hline & Instagram & $11.2 \%$ & $10.8 \%$ & $10.9 \%$ & 0.902 \\
\hline & Print Newspapers & $11.2 \%$ & $11.8 \%$ & $11.6 \%$ & 0.870 \\
\hline & Other Online Wine Websites & $11.2 \%$ & $5.4 \%$ & $7.6 \%$ & $0.063^{*}$ \\
\hline & Wine Apps & $8.6 \%$ & $4.3 \%$ & $6.0 \%$ & 0.123 \\
\hline & Twitter & $6.9 \%$ & $2.2 \%$ & $4.0 \%$ & $0.040^{* *}$ \\
\hline & Trip Advisor & $6.9 \%$ & $6.5 \%$ & $6.6 \%$ & 0.880 \\
\hline & Online wine magazines & $6.0 \%$ & $3.8 \%$ & $4.6 \%$ & 0.361 \\
\hline & YouTube & $4.3 \%$ & $4.3 \%$ & $4.3 \%$ & 0.997 \\
\hline & QR Codes & $2.6 \%$ & $0.0 \%$ & $1.0 \%$ & $0.028 * *$ \\
\hline
\end{tabular}

\section{PURCHASING BEHAVIOR}

Of the five alcoholic beverage types listed in Table 22, every respondent in the target group indicated they had purchased wine during the previous year in contrast to those in the nontarget group (93\%). The target group wine enthusiasts are not only interested in a wine's provenance, but they have been motivated by that interest to purchase wine. Likewise, it is also important to note that craft beer was purchased by a significantly greater proportion of the target group $(72 \%)$ than the non-target group $(60 \%)$. The shared artistic element of wine making and craft beer brewing may be appreciated more by the target group than the non-target group.

Regardless of the underlying reason, this finding is meaningful because craft beer is gaining in popularity as a wine substitute (Manning, 2013).

Table 22: Types of Alcoholic Beverages Consumers Purchased.

\begin{tabular}{|c|l|c|c|c|c|}
\hline \multirow{2}{*}{ Beverage Types } & $\begin{array}{c}\text { Always; } \\
\text { Very Often } \\
(\mathrm{N}=116)\end{array}$ & $\begin{array}{c}\text { Somewhat; } \\
\text { Not Very; } \\
\text { Never } \\
(\mathrm{N}=186)\end{array}$ & $\begin{array}{c}\text { Total } \\
(\mathrm{N}=302)\end{array}$ & Chi-Square \\
\hline \multirow{2}{*}{$\begin{array}{c}\text { Which of the } \\
\text { following } \\
\text { have you } \\
\text { purchased } \\
\text { in the past } \\
\text { year? }\end{array}$} & Beer & $82.8 \%$ & $80.6 \%$ & $81.5 \%$ & 0.646 \\
\cline { 2 - 6 } & Craft Beer & $71.6 \%$ & $60.2 \%$ & $64.6 \%$ & $0.045^{* *}$ \\
\cline { 2 - 6 } & Wine & $100.0 \%$ & $93.0 \%$ & $95.7 \%$ & $0.004^{* *}$ \\
\cline { 2 - 6 } & Sparkling Wine & $57.8 \%$ & $48.9 \%$ & $52.3 \%$ & 0.135 \\
\cline { 2 - 6 } & None of the above & $65.5 \%$ & $60.2 \%$ & $62.3 \%$ & 0.355 \\
\hline
\end{tabular}

${ }^{* *}$ Significant at the .05 level 
The top three most popular wine varietals selected for purchase by both consumer groups were: 1) Cabernet Sauvignon; 2) Chardonnay; and 3) Pinot Noir. Furthermore, there was no significant difference between the two groups when Chardonnay, Pinot Noir or Pinot Grigio was selected for purchase as indicated in Table 23. This suggests the place-of-origin for these three varietals is equally important to both groups. However, the provenance of the other varietals and blends listed is significantly more important to the target group than it is to the non-target group. The wine enthusiasts that always, or very often consider place-of-origin when selecting wines for purchase are serious about where these four varietals and three blends originate.

Table 23: Varietals and Blends Consumers Purchased.

\begin{tabular}{|c|c|c|c|c|c|}
\hline & Wine Varietals and Blends & $\begin{array}{c}\text { Always; } \\
\text { Very Often } \\
(\mathrm{N}=116)\end{array}$ & $\begin{array}{l}\text { Somewhat; } \\
\text { Not Very; } \\
\text { Never } \\
(\mathrm{N}=186)\end{array}$ & $\begin{array}{c}\text { Total } \\
(\mathrm{N}=302)\end{array}$ & Chi-Square \\
\hline \multirow{11}{*}{$\begin{array}{l}\text { Which of the } \\
\text { following } \\
\text { varietals or } \\
\text { blends have } \\
\text { you } \\
\text { purchased in } \\
\text { the past } \\
\text { year? } \\
\text { Choose all } \\
\text { that apply. }\end{array}$} & Cabernet Sauvignon & $72.4 \%$ & $58.1 \%$ & $63.6 \%$ & $0.012^{* *}$ \\
\hline & Chardonnay & $63.8 \%$ & $58.1 \%$ & $60.3 \%$ & 0.322 \\
\hline & Merlot & $51.7 \%$ & $39.2 \%$ & $44.0 \%$ & $0.034^{* *}$ \\
\hline & Pinot Grigio & $33.6 \%$ & $31.2 \%$ & $32.1 \%$ & 0.659 \\
\hline & Pinot Noir & $59.5 \%$ & $56.5 \%$ & $57.6 \%$ & 0.604 \\
\hline & Sauvignon Blanc & $45.7 \%$ & $30.6 \%$ & $36.4 \%$ & $0.008^{* *}$ \\
\hline & Shiraz/Syrah & $41.4 \%$ & $24.2 \%$ & $30.8 \%$ & $0.002^{* *}$ \\
\hline & Rhone Blend & $25.0 \%$ & $5.4 \%$ & $12.9 \%$ & $0.000^{* *}$ \\
\hline & Red Blend & $58.6 \%$ & $46.2 \%$ & $51.0 \%$ & $0.036^{* *}$ \\
\hline & White Blend & $31.0 \%$ & $20.4 \%$ & $24.5 \%$ & $0.037^{* *}$ \\
\hline & $\begin{array}{l}\text { I don't know which varietals or blends I } \\
\text { purchase }\end{array}$ & $1.7 \%$ & $9.1 \%$ & $6.3 \%$ & $0.010^{\star *}$ \\
\hline
\end{tabular}

** Significant at the .05 level

Table 24 indicates there was no statistical difference found between the average number of wine bottles the target group and the non-target group purchased from a retail outlet every month.

Table 24: Number of Wine Bottles Purchased Monthly.

\begin{tabular}{|c|c|c|c|c|}
\hline & $\begin{array}{l}\text { Always; } \\
\text { Very } \\
\text { Often } \\
(\mathrm{N}=116)\end{array}$ & $\begin{array}{c}\text { Somewhat; } \\
\text { Not Very; } \\
\text { Never } \\
(\mathrm{N}=186) \\
\end{array}$ & $\begin{array}{c}\text { Total } \\
\text { Mean } \\
(\mathrm{N}=302)\end{array}$ & P-Value ${ }^{\wedge}$ \\
\hline $\begin{array}{l}\text { Approximately how many bottles of wine do you typically buy per } \\
\text { month at a retail outlet? }\end{array}$ & 6.035 & 4.611 & 5.15 & 0.225 \\
\hline
\end{tabular}

^Independent Sample t-test

However, the target group did spend $24 \%$ more on average for a bottle of wine than the non-target group did as highlighted in Table 25. Awareness of wine region or AVA, and the 
perceived quality of a wine's provenance, are two very important factors influencing the target group's willingness to pay a significantly higher price point for a bottle of wine than the nontarget group that is not as interested in place-of-origin.

Table 25: Average Wine Bottle Purchase Price.

\begin{tabular}{|c|c|c|c|c|}
\hline 1able 25: Average wine bottle Purchase Price. & \multicolumn{2}{|c|}{ Mean } & \multirow[b]{2}{*}{$\begin{array}{l}\text { Total Mean } \\
(\mathrm{N}=302)\end{array}$} & \multirow[b]{2}{*}{ P-Value } \\
\hline & $\begin{array}{c}\text { Always; } \\
\text { Very Often } \\
(\mathrm{N}=116)\end{array}$ & $\begin{array}{c}\text { Somewhat; } \\
\text { Not Very; } \\
\text { Never } \\
(\mathrm{N}=186) \\
\end{array}$ & & \\
\hline $\begin{array}{c}\text { Approximately how much do you spend on a bottle of wine } \\
\text { at a retail outlet? }\end{array}$ & $\$ 15.59$ & $\$ 12.58$ & $\$ 14.00$ & $0.004^{* *}$ \\
\hline
\end{tabular}

^Independent Sample t-test

${ }^{*}$ Significant at the .05 level

The question asking for an approximate cost-per-bottle price range confirms the previous findings in Table 25. Almost $46 \%$ of the target group indicated the off-premise price for wine purchased by-the-bottle was in the $\$ 15.00$ - $\$ 24.99$ range, with another $10 \%$ buying wines costing $\$ 25.00$ - $\$ 74.99$. While a large majority of the target group bought wines in the higher price ranges of $\$ 15.00$ - $\$ 74.99$, almost three-fourths of the non-target group made wine purchases in the two lowest $\$ 0.00$ - $\$ 14.99$ price ranges as shown in Table 26 .

Table 26: Price Range of 750ml Wine Bottle Purchased.

\begin{tabular}{|c|c|c|c|c|c|}
\hline & Price Ranges & $\begin{array}{l}\text { Always; } \\
\text { Very Often } \\
(\mathrm{N}=116)\end{array}$ & $\begin{array}{l}\text { Somewhat; } \\
\text { Not Very; } \\
\text { Never } \\
(\mathrm{N}=186)\end{array}$ & $\begin{array}{c}\text { Total } \\
(\mathrm{N}=302)\end{array}$ & $\begin{array}{c}\text { Chi- } \\
\text { Square }\end{array}$ \\
\hline \multirow{6}{*}{$\begin{array}{l}\text { What price range best represents the } \\
\text { majority of your wine bottle purchases } \\
\text { at a retail outlet }(750 \mathrm{ml}) ?\end{array}$} & $\$ 0.00-\$ 9.49$ & $11.2 \%$ & $28.3 \%$ & $21.7 \%$ & \multirow{6}{*}{$0.000^{* *}$} \\
\hline & $\$ 9.50-\$ 14.99$ & $31.9 \%$ & $43.5 \%$ & $39.0 \%$ & \\
\hline & $\$ 15.00-\$ 24.99$ & $45.7 \%$ & $22.3 \%$ & $31.3 \%$ & \\
\hline & $\$ 25.00-\$ 49.99$ & $10.3 \%$ & $4.9 \%$ & $7.0 \%$ & \\
\hline & $\$ 50.00-\$ 74.99$ & $0.9 \%$ & $0.0 \%$ & $0.3 \%$ & \\
\hline & $\$ 75.00+$ & $0.0 \%$ & $1.1 \%$ & $0.7 \%$ & \\
\hline
\end{tabular}

${ }^{* *}$ Significant at the .05 level

The consumer portion of this study that focused on the wine buying activities of both groups also looked at on-premise wine purchases either by-the-glass or by-the-bottle. On average the target group did not buy a noticeably greater number of wines-by-the-glass than those not influenced by wine region. However, a significant finding highlighted in Table 27 revealed that the target group purchased more than twice as many wine bottles per month from on-premise retail business establishments than the non-target group did. 
Table 27: Monthly On-Premise Wine Purchased.

\begin{tabular}{|c|c|c|c|c|c|}
\hline & & $\begin{array}{c}\text { Always; } \\
\text { Very Often } \\
(\mathrm{N}=116)\end{array}$ & $\begin{array}{c}\text { Somewhat; } \\
\text { Not Very; } \\
\text { Never } \\
(\mathrm{N}=186)\end{array}$ & $\begin{array}{c}\text { Total } \\
\text { Mean } \\
(\mathrm{N}=302)\end{array}$ & P-Value $^{\wedge}$ \\
\hline $\begin{array}{c}\text { Approximately how many glasses and/or bottles } \\
\text { of wine do you typically buy per month at a } \\
\text { restaurant or bar? }\end{array}$ & Glasses & 2.74 & 2.28 & 2.48 & 0.190 \\
\cline { 2 - 7 } & Bottles & 1.11 & $\mathbf{0 . 5 1}$ & $\mathbf{0 . 7 4}$ & $0.018^{\star *}$ \\
\hline
\end{tabular}

Independent Sample t-test

**Significant at the .05 level

According to findings displayed in Table 28, results from the consumer survey found that $16 \%$ of the total wine purchasers did not know the specific grape growing region their wines were sourced from. This may reflect nonexistent, or ineffective regional promotional efforts made by the wine brands that were selected. Regardless of any marketing attempts made it appears to have had little impact on the respondents that could not recall the grape growing region.

However, for the target group, Paso Robles, the Central Coast, Sonoma County, and Arroyo Grande Valley wine regions were more highly regarded as wine sources compared to the nontarget group. The regional reputations of these four wine regions significantly influenced the target group's wine buying decisions.

Table 28: Consumer Wine Purchases by Region.

\begin{tabular}{|c|c|c|c|c|c|}
\hline & Wine Regions & $\begin{array}{l}\text { Always; } \\
\text { Very Often } \\
(\mathrm{N}=116)\end{array}$ & $\begin{array}{l}\text { Somewhat; } \\
\text { Not Very; } \\
\text { Never } \\
(\mathrm{N}=186)\end{array}$ & $\begin{array}{c}\text { Total } \\
(\mathrm{N}=302)\end{array}$ & Chi-Square \\
\hline \multirow{12}{*}{$\begin{array}{l}\text { In the past } \\
\text { year when } \\
\text { you } \\
\text { purchased } \\
\text { wine, from } \\
\text { which of the } \\
\text { following } \\
\text { wine grape } \\
\text { growing } \\
\text { regions did } \\
\text { the wine } \\
\text { come? }\end{array}$} & Paso Robles & $83.6 \%$ & $62.9 \%$ & $70.9 \%$ & $0.000^{* *}$ \\
\hline & Arroyo Grande Valley & $25.9 \%$ & $17.7 \%$ & $20.9 \%$ & $0.091^{*}$ \\
\hline & Sonoma County & $57.8 \%$ & $43.0 \%$ & $48.7 \%$ & $0.013^{* *}$ \\
\hline & Central Coast & $74.1 \%$ & $48.4 \%$ & $58.3 \%$ & $0.000^{* *}$ \\
\hline & Napa Valley & $64.7 \%$ & $59.7 \%$ & $61.6 \%$ & 0.387 \\
\hline & Edna Valley & $52.6 \%$ & $43.0 \%$ & $46.7 \%$ & 0.105 \\
\hline & Sierra Foothills & $7.8 \%$ & $7.5 \%$ & $7.6 \%$ & 0.941 \\
\hline & York Mountain & $6.0 \%$ & $3.2 \%$ & $4.3 \%$ & 0.242 \\
\hline & Santa Rita Hills & $10.3 \%$ & $8.1 \%$ & $8.9 \%$ & 0.499 \\
\hline & None of the above & $1.7 \%$ & $1.6 \%$ & $1.7 \%$ & 0.941 \\
\hline & Other & $20.7 \%$ & $14.5 \%$ & $16.9 \%$ & 0.164 \\
\hline & $\begin{array}{l}\text { I DO NOT KNOW which grape growing } \\
\text { regions my wine comes from }\end{array}$ & $3.4 \%$ & $24.2 \%$ & $16.2 \%$ & $0.000^{* *}$ \\
\hline
\end{tabular}

*Significant at the .10 level

${ }^{*}$ Significant at the .05 level

\section{ATTITUDES TOWARD WINE REGIONS}

To determine how familiar the total wine consumer sample was with the nine listed wine grape growing regions, they were asked to indicate their level of familiarity using a 5-point rating scale where 5 = Extremely Familiar; $4=$ Very Familiar; $3=$ Somewhat Familiar; $2=$ Not Very 
Familiar; and $1=$ Not Familiar at All. The wine regions were sorted in descending order by their mean rating, and a paired sample t-test was performed to check for significant differences between the listed regions for the entire sample as shown in Table 29. Findings indicate the wine consumers rated Paso Robles and Napa Valley as being equally familiar. However, Napa Valley was more familiar to the wine consumers than the Central Coast. The wine consumers considered the Central Coast and Sonoma County equally familiar, as they did Sonoma County and Edna Valley. However, the wine consumers rated Edna Valley more familiar than Arroyo Grande Valley, and Arroyo Grande Valley was rated more familiar than Sierra Foothills. The wine consumers were equally familiar with Sierra Foothills and Santa Rita Hills, and finally, Santa Rita Hills was rated more familiar to the wine consumers than York Mountain was.

Table 29: Rated Familiarity Paired Sample T-Test.

\begin{tabular}{|c|c|c|c|}
\hline & Wine Regions & $\begin{array}{l}\text { Total Means } \\
\quad(\mathrm{N}=302)\end{array}$ & P-Value ${ }^{\wedge}$ \\
\hline \multirow{9}{*}{$\begin{array}{l}\text { How familiar are } \\
\text { you with the } \\
\text { following wine } \\
\text { grape growing } \\
\text { regions? }\end{array}$} & Paso Robles & 3.79 & - \\
\hline & Napa Valley & 3.68 & 0.106 \\
\hline & Central Coast & 3.46 & $0.002^{* *}$ \\
\hline & Sonoma County & 3.36 & 0.171 \\
\hline & Edna Valley & 3.24 & 0.110 \\
\hline & Arroyo Grande Valley & 2.86 & $0.000^{* *}$ \\
\hline & Sierra Foothills & 1.98 & $0.000^{* *}$ \\
\hline & Santa Rita Hills & 1.89 & 0.147 \\
\hline & York Mountain & 1.77 & $0.017^{* *}$ \\
\hline \multicolumn{4}{|c|}{$\begin{array}{l}\text { (5 = Extremely Familiar; } 4 \text { = Very Familiar; } 3 \text { = Somewhat Familiar; } 2 \text { = Not Very Familiar; } \\
1 \text { = Not Familiar at all) } \\
\text { ^Paired Sample t-test } \\
\text { **Significant at the } .05 \text { level }\end{array}$} \\
\hline
\end{tabular}

Nine geographic areas were examined to understand how familiar the wine consumers were with each region, as well as its perceived wine quality. Respondents were asked how familiar they were with nine listed wine regions. Available choices consisted of a 5-point scale where 5 = Extremely Familiar; 4 = Very Familiar; 3 = Somewhat Familiar; 2 = Not Very Familiar; and 1 = Not Familiar at All, from which mean ratings were determined. Of the eight designated AVAs, and the one regional wine area listed in the survey, the total consumer respondents rated Paso Robles, Napa Valley and the Central Coast AVAs as the most wellknown of California's larger winegrowing regions, with Sonoma County listed fourth as displayed in Table 30. Furthermore, the target group were significantly more familiar with the 
top five wine AVAs or wine regions listed. Findings also indicated that the Santa Rita Hills $($ mean $=1.89)$, and York Mountain $($ mean $=1.77)$ AVAs were not very familiar to the total consumer sample unlike the total wine trade survey participants that rated the Santa Rita Hills AVA (mean $=4.37)$ as being very familiar (see Table 7 as reference only).

Table 30: Consumer Rated Region Familiarity.

\begin{tabular}{|c|c|c|c|c|c|}
\hline \multicolumn{2}{|c|}{ Table 30: Consumer Rated Region Familiarity. } & \multicolumn{2}{|c|}{ Mean } & \multirow[b]{2}{*}{$\begin{array}{c}\text { Total } \\
\text { Means } \\
(\mathrm{N}=302)\end{array}$} & \multirow[b]{2}{*}{ P-Value ${ }^{\wedge}$} \\
\hline & Wine Regions & $\begin{array}{c}\text { Always; } \\
\text { Very } \\
\text { Often } \\
(\mathrm{N}=116) \\
\end{array}$ & $\begin{array}{c}\text { Somewhat; } \\
\text { Not Very; } \\
\text { Never } \\
(\mathrm{N}=186)\end{array}$ & & \\
\hline \multirow{9}{*}{$\begin{array}{l}\text { How familiar are you } \\
\text { with the following wine } \\
\text { grape growing regions? }\end{array}$} & Paso Robles & 4.00 & 3.65 & 3.79 & $0.040^{* *}$ \\
\hline & Napa Valley & 3.86 & 3.56 & 3.68 & $0.020^{* *}$ \\
\hline & Central Coast & 3.76 & 3.27 & 3.46 & $0.000^{* *}$ \\
\hline & Sonoma County & 3.59 & 3.22 & 3.36 & $0.007^{* *}$ \\
\hline & Edna Valley & 3.45 & 3.10 & 3.24 & $0.011^{* *}$ \\
\hline & Arroyo Grande Valley & 2.90 & 2.83 & 2.86 & 0.557 \\
\hline & Sierra Foothills & 1.95 & 1.98 & 1.98 & 0.754 \\
\hline & Santa Rita Hills & 1.93 & 1.87 & 1.89 & 0.603 \\
\hline & York Mountain & 1.80 & 1.75 & 1.77 & 0.681 \\
\hline
\end{tabular}

To determine how the total consumer sample rated wine quality from the nine wine grape growing regions, a 5-point rating scale was used where $5=$ Excellent Quality; $4=$ Very Good Quality; 3 = Somewhat Good Quality; 2 = Not Very Good Quality; and 1 = Poor Quality. The wine regions were sorted in descending order by their mean rating, and a paired sample t-test was performed to check for significant differences between the listed regions for the entire consumer sample as shown in Table 31. The consumer sample considered Napa Valley wines higher in quality than Paso Robles wines. However, Paso Robles wine quality was rated the same as Sonoma County. Wines from Sonoma County were rated higher than wines from the Central Coast. Central Coast wines were rated higher in quality than Edna Valley wines, and Edna Valley wines were considered higher in quality than wines from Arroyo Grande Valley. The consumer sample rated Arroyo Grande Valley wines of higher quality than Santa Rita Hills wines. Wines from Santa Rita Hills were considered higher in quality than wines from Sierra Foothills, as well as Sierra Foothills wines being perceived higher in quality than wines from York Mountain. 
Table 31: Rated Quality Paired Sample T-Test.

\begin{tabular}{|c|c|c|c|}
\hline & Wine Regions & $\begin{array}{l}\text { Total Means } \\
(\mathrm{N}=302)\end{array}$ & P-Value ${ }^{\wedge}$ \\
\hline \multirow{9}{*}{$\begin{array}{c}\text { Based on your perceptions, how } \\
\text { would you rate the QUALITY of } \\
\text { the wine produced in the } \\
\text { following wine grape growing } \\
\text { regions? }\end{array}$} & Napa Valley & 4.53 & - \\
\hline & Paso Robles & 4.10 & $0.000^{* *}$ \\
\hline & Sonoma County & 4.09 & 0.908 \\
\hline & Central Coast & 3.86 & $0.000^{* *}$ \\
\hline & Edna Valley & 3.74 & $0.044^{* *}$ \\
\hline & Arroyo Grande Valley & 3.36 & $0.000^{* *}$ \\
\hline & Santa Rita Hills & 2.89 & $0.000^{* *}$ \\
\hline & Sierra Foothills & 2.79 & $0.008^{* *}$ \\
\hline & York Mountain & 2.70 & $0.086^{*}$ \\
\hline
\end{tabular}

The wine consumers were asked to rate the wine quality from the same nine wine regions listed to measure familiarity. Answers to this question consisted of a 5-point rating scale where 5 = Excellent Quality; 4 = Very Good Quality; 3 = Somewhat Good Quality; 2 = Not Very Good Quality; and 1 = Poor Quality, from which mean ratings were determined and displayed in Table 32. Regional quality perceptions made by consumers that make wine purchases based on winegrowing regions were similar to the familiarity findings in Table 30. Although Napa Valley, Paso Robles and Sonoma County were rated the top three wine regions based on perceived quality, those same wine buyers considered wines from the Santa Rita Hills (mean =2.89) and York Mountain $($ mean $=2.70)$ AVAs as not very good quality, and also from wine regions that were not very familiar to them. Again, this is in contrast to the wine trade respondents that considered wines from the Santa Rita Hills AVA (mean = 4.43) to be very good quality (see Table 9 as reference only).

Table 32: Consumer Rated Quality by Region. 


\section{ATTITUDES TOWARD WINE CHARACTERISTICS}

Rating the six desirability factors of the consumer sample consisted of using a 5-point scale where 5 = Extremely Desirable; 4 = Very Desirable; $3=$ Somewhat Desirable $; 2=$ Not Very Desirable; and 1 = Not Desirable at All. These factors were sorted in descending order by their mean rating, and a paired sample t-test was performed to test for significant differences between the features for the entire sample as shown in Table 33. Findings indicate the wine consumers rated Good value for the money more desirable than Varietal I like. They also considered Varietal I like as a more desirable feature than a Premium quality product. Consumers also rated Premium quality product higher than Label identifies the growing region. However, they considered Label identifies the growing region the same as Grapes are from a respected wine grape growing region (no significant difference). Lastly, Grapes are from a respected wine grape growing region was rated higher than Sustainably produced.

Table 33: Rated Desirability Paired Sample T-Test.

\begin{tabular}{|c|c|c|c|}
\hline & Desirability Features & $\begin{array}{l}\text { Total } \\
\text { Means }\end{array}$ & P-Value ${ }^{\wedge}$ \\
\hline \multirow{6}{*}{$\begin{array}{l}\text { Indicate the } \\
\text { desirability of each } \\
\text { feature when you } \\
\text { purchase wine for } \\
\text { yourself. }\end{array}$} & Good value for the money & 4.39 & - \\
\hline & Varietal I like & 4.24 & $0.017^{* *}$ \\
\hline & Premium quality product & 4.00 & $0.000^{* *}$ \\
\hline & Label identifies the growing region & 3.32 & $0.000^{\star *}$ \\
\hline & $\begin{array}{l}\text { Grapes are from a respected wine } \\
\text { grape growing region }\end{array}$ & 3.27 & 0.469 \\
\hline & Sustainably produced & 2.87 & $0.000^{* *}$ \\
\hline \multicolumn{4}{|c|}{$\begin{array}{l}\text { (5 = Extremely Desirable; } 4 \text { = Very Desirable; } 3 \text { = Somewhat Desirable; } 2 \text { = Not Very Desirable; } \\
1=\text { Not Desirable at all) } \\
\text { ^Paired Sample t-test } \\
{ }^{* *} \text { Significant at the } .05 \text { level }\end{array}$} \\
\hline
\end{tabular}

Wine consumers were asked to rate six different features by desirability when making a decision to purchase wine. The two most desirable features indicated by the total respondents surveyed were: 1) Good value for the money, and 2) Varietal I like, while Grapes from a respected grape growing region $($ mean $=3.27)$ was considered only a somewhat desirable trait. These findings were not surprising since $16 \%$ of the total wine consumers also indicated they did not know the place-of-origin of the wines they purchased (see Table 28). For the non-target group, Good Value for the money $($ mean $=4.47)$ was considered a significantly more desirable 
trait than the target group did $($ mean $=4.28)$. However, for the target group, Grapes are from a respected grape growing region $($ mean $=4.22)$ was considered a very desirable trait when making a decision to purchase wine. Moreover, the target group rated the other five desirability features as significantly more important to them when making a wine purchasing decision than the nontarget group did. Results are outlined in Table 34.

Table 34: Consumer Rated Desirability Features.

\begin{tabular}{|c|c|c|c|c|c|}
\hline \multicolumn{2}{|c|}{ Table 34: Consumer Rated Desirability Features. } & \multicolumn{2}{|c|}{ Mean } & \multirow[b]{2}{*}{$\begin{array}{c}\text { Total } \\
\text { Means }\end{array}$} & \multirow[b]{2}{*}{ P-Value $^{\wedge}$} \\
\hline & Desirability Features & $\begin{array}{c}\text { Always; } \\
\text { Very Often } \\
(\mathrm{N}=116)\end{array}$ & $\begin{array}{c}\text { Somewhat; } \\
\text { Not Very; } \\
\text { Never } \\
(\mathrm{N}=186)\end{array}$ & & \\
\hline \multirow{6}{*}{$\begin{array}{l}\text { Indicate the } \\
\text { desirability of } \\
\text { each feature } \\
\text { when you } \\
\text { purchase } \\
\text { wine for } \\
\text { yourself. }\end{array}$} & Good value for the money & 4.28 & 4.47 & 4.39 & $0.039 * *$ \\
\hline & Varietal I like & 3.84 & 2.91 & 4.24 & $0.002^{* *}$ \\
\hline & Premium quality product & 4.43 & 4.11 & 4.00 & $0.000^{* *}$ \\
\hline & Label identifies the growing region & 3.13 & 2.70 & 3.32 & $0.000^{* *}$ \\
\hline & $\begin{array}{l}\text { Grapes are from a respected wine grape } \\
\text { growing region }\end{array}$ & 4.22 & 3.86 & 3.27 & $0.000^{\star *}$ \\
\hline & Sustainably produced & 4.03 & 2.86 & 2.87 & $0.001^{* *}$ \\
\hline
\end{tabular}

( 5 = Extremely Desirable; 4 = Very Desirable; 3 = Somewhat Desirable; 2 = Not Very Desirable; 1 = Not Desirable at all)

^Independent Sample t-test

${ }^{* *}$ Significant at the .05 level 


\section{CONCLUSIONS AND RECOMMENDATIONS}

Previous research into wine trade and consumer purchasing behaviors has shown there are a few key indicators influencing their buying choices. Bruwer and Johnson (2010) pointed out how consumers can be inundated by the sheer complexity of the buying situation when there are so many wine brands to choose from, and how place-of-origin is widely being accepted as an indispensable differentiation strategy. Today there is a mind-boggling array of wine brands jostling for position on the shelves of off-premise stores, as well as screaming out "Try Me!" from the wine lists of on-premise businesses. Does the emphasis of place-of-origin within a regional branding context stimulate the domestic wine industry to increase the number of smaller American Viticultural Areas (AVAs), or is it the other way around? Earlier studies have shown that consumers do respond to regional branding cues when evaluating comparative wine labels and how it influences buyer confidence in a product's quality. Yet how much of an influence does an established AVA have on the purchasing behaviors of those making wine buying decisions? More importantly, what are both the wine trade and the typical wine consumer willing to pay based on the reputation of a wine region? For the target group consumers, results from this study show they were willing to pay more for a bottle of wine from retail outlets, and buy more bottles of wine at on-premise sites than the non-target group were (see Tables 25 and 27).

Results of this study also indicated that wine trade buyers, regarded as distribution channel gatekeepers, placed a greater importance on the place-of-origin of wines chosen for resale than regular consumers did when making personal buying decisions. These findings suggest that the motives underlying the procurement process of these two groups are formed by different objectives. The wine trade buyer will primarily be interested in one crucial financial consideration: the margin of return on their wholesale wine investment. This is understandable since they have a retail business to run. Conversely, the regular wine consumer, regardless of their level of sophistication, is primarily interested in the experiential enjoyment or shared 
element of the wines they purchase. Apart from membership in the very exclusive wine buyer ranks that purchase wine solely as collectors, it is reasonable to assume the average consumer buying value-priced wines costing below $\$ 10.00$ will be more inclined to drink them shortly after purchase.

The target group segment from both surveys in this study focused on wine buyers that indicated they always, or very often make purchasing decisions based on where the wine was produced. However, when the Somewhat often decision qualifier is included, $81 \%$ of trade respondents indicated a wine's place-of-origin influenced their choice (see Table 1) compared to $69 \%$ of regular wine consumers (see Table 19). Of the ten retail business categories selling wine, $59 \%$ of the restaurants indicated they always, or very often were influenced by where the wines were produced. This suggests that the target group wine buyers for restaurants place a greater importance upon place-of-origin than the other nine business categories, as well as implying a heightened level of awareness of how wine regions impact their on-premise wine sales. This is a much higher percentage than either the target group retail wine shop (21\%), or wine bar (23\%) purchasers indicated in their responses to the same question (see Table 2).

As a business category, restaurants were the only ones surveyed whose main purpose is serving food, not wine. Restaurant owners understand how food quality and the level of service provided, when combined with the overall atmosphere associated with their business, coalesces into the ambience that directly impacts customer moods. Since wine has become more popular as a paired beverage with food, serving wine with its own established brand image of quality may actually enhance the overall dining experience for patrons. If the wine list is limited, offering wines from well-known regions just might help overcome customer selection hesitation due to the unfamiliarity of lesser-known wine areas.

When assessing the quality of wines produced in the listed California wine regions, the total wine trade sample rated the considerably smaller Santa Rita Hills AVA (mean $=4.43$ ) higher than the more extensive Central Coast AVA (mean = 3.96; see Table 9), even though they 
indicated they were more familiar with the Central Coast AVA (mean $=4.58$; see Table 7). This may suggest promotion efficiency by the Santa Rita Hills Winegrowers Alliance in championing the quality of its wines to wine trade buyers compared to the impact it has had on typical wine consumers.

The larger Central Coast AVA is a good example of a sizeable multi-county wine area that could be too expansive to effectively convey a unified regional identity. This expansive AVA, established November 25, 1985, encompasses 6.8 million acres from portions of eight counties, and currently has 38 smaller AVAs nestled within it. Spanning nearly 250 miles along the California coastline from San Francisco City/County in the north, to Santa Barbara County in the south, this vast AVA has approximately 100,000 acres planted in wine grapes. In this instance, a good case could be made for revisiting the extensive boundaries and separating out the coastal counties from the inland counties that are not bordered by the Pacific Ocean. The five counties that are bounded by the Pacific Ocean; San Mateo; Santa Cruz; Monterey; San Luis Obispo, and Santa Barbara, should be considered part of a more precise Central Coast AVA designation. Even then, the three largest of these counties; Monterey, San Luis Obispo, and Santa Barbara, would require further review to determine how to divide any existing or future AVAs into coastal versus inland sub-regions. It is also recommended that any existing or new AVAs grouped into the coastal category maintain the overarching regional identity by adopting the conjunctive labeling promotional policy. The collective identifier "Central Coast" would be required to appear on all wine labels that also identify a smaller AVA nested within the encompassing region.

Results of this study also revealed how wine trade buyers were more aware of the California wine regions mentioned in its survey, compared to the wine consumer familiarity of those same regions (see Tables 7 and 30). Likewise, the wine trade buyers that always, or very often make purchasing decisions based on place-of-origin rated the quality of wines from those same regions higher than the consumers did (see Tables 9 and 32). This greater appreciation of a 
wine's provenance can be exploited by lesser-known wine regions that want to attract the attention of wine trade buyers, and ultimately, wine consumers from outside their local area. Because wine trade buyers act as gatekeepers by selecting what is eventually offered to the enduser, up-and-coming wine regions should do more to educate the wine trade about their area's unique winegrowing characteristics. Although no useful comparisons can be made between the wine trade sample and the wine consumer sample for the purposes of this study (no relationship was implied), it is recommended that any future studies involving the wine trade focus on its targeted customer demographic to add validity to the findings.

When considering the consumer's point-of-view however, caution is warranted regarding the expected financial boon from establishing new AVAs. Since AVAs are the darlings of wine insiders that insist their terroir gerrymandering better represents a viticultural Shangri-La, doing so can confuse, rather than captivate wine consumer attention. Any benefit to vineyards and wineries within the borders of newly established AVAs depends on sufficient relevance of the sub-region to existing and future wine consumers. Nevertheless, if informed consumers are willing to pay higher prices for wines from better known regions, then enhancing quality perceptions must be paramount for the regional winegrower.

Since creating smaller AVAs often results in fewer resident vineyards and wineries included within its constricted borders, collaborative efforts that foster regional differentiation are highly recommended. The synergy of collective promotional monies and energies will be far more effective than Lone Ranger marketing approaches. Taking a cue from the Schamel and Anderson (2003) study, riding the coattails of established quality reputations through the phenomenon called reputation tapping should be considered. This simple strategy links the more prominent foreign or domestic regional cluster to the less renowned AVA. This will limit consumer confusion, make an immediate impression denoting quality, and speed up the reputation status of any newly established AVA. Realizing there is a positive impact that can be gained by referring to place-of-origin on wine labels and in promotional efforts, vineyards and 
wineries have a simple, yet compelling tactic, linking the quality perceptions of its winemaking efforts to the distinctive terroir the grapes were sourced from.

After considerable review of the findings provided by the two surveys included in this study, it is highly recommended to build upon the promising insight the wine trade can provide due to their unique retail gatekeeper role. Inviting this segment of the three-tier alcohol distribution system to participate in more detailed surveys should be undertaken to better understand the business pressures of choosing one wine over another for resale. What makes one wine a better resale value over its competition? What wine region promotional efforts have had an effective influence on the purchasing behavior of the wine trade? Answers to these and related questions would help small to medium sized wineries better allocate limited promotional budgets toward educating the wine trade more successfully. It would also be helpful to better categorize any retail businesses by some easily determined indicator of size, sales volume, price points and clientele served.

The following suggestions are also a result from reassessing the two survey instruments that are central to the purpose of this study. After the extensive analysis of responses made by the wine trade and wine consumers, it is strongly recommended that any future survey development standardize lists that are included for rating and comparison purposes. For example, the following lists should be exactly the same for the sake of clarity: types of alcoholic beverages selected (Tables 3 and 22); varietals and blends selected (Tables 4 and 23); places-of-origin of wine purchases (Tables 5 and 28); wine region familiarity (Tables 7 and 30); wine region quality perceptions (Tables 9 and 32); and lastly, the list of wine desirability features (Tables 11 and 34).

Final recommendations regarding the future wording of survey questions suggest how demographic categories, or other quantifiable research data, should be displayed when contrasted with secondary market research resources such as MRI+ MediaMark and Global Market Information Database (GMID). All such lists, data ranges, or survey responses intended to be compared to secondary data should mirror the same content and format which the secondary 
source information employs. After all, to use a wine grape analogy, such comparisons should be Pinot Noir-to-Pinot Noir, not Pinot Noir-to-Pinot Gris. 


\section{BIBLIOGRAPHY}

"11 new viticultural areas established within Paso Robles." 2014. Paso Robles Daily News. (October 8) Wine Section. http://pasoroblesdailynews.com.

Atkin, T.S., and S.K. Newton. 2012. "Consumer awareness and quality perceptions: a case for Sonoma County wines." Journal of Wine Research. (23:2) pp. 155-171.

Bruwer, J. and R. Johnson. 2010. "Place-based marketing and regional branding strategy perspectives in the California wine industry." Journal of Consumer Marketing. (27:1) pp. 5-16.

Cattell, H. 2009. “TTB Approves Largest AVA.” Wines \& Vines. July 9, 2009. Retrieved May 4, 2015, from http://www.winesandvines.com.

Esterlina Vineyards \& Winery. “About Us.” Web. Retrieved April 20, 2015, from http://www.esterlinavineyards.com/about-us.html.

Franson, P. 2011. "Napa winegrowers aim 'Ahead of the Curve'." Wines \& Vines. March 9, 2011. Retrieved May 4, 2015, from http//from www.winesandvines.com.

Jarvis, W. and S. Goodman. 2005. "Effective Marketing of Small Brands: Niche Positions, Attribute Loyalty and Direct Marketing." Journal of Product and Brand Management. (14:5) pp. 292-299.

Johnson, R. 2011. "What is an AVA and What Does the Wine Market Tell Us about AVAs?" Paper presented at the AIPLA Spring Meeting, San Francisco, May 12-14, 2011. http://www.aipla.org/2011/spring/MATERIALS/JohnsonRay_Paper.pdf.

Johnson, R. and J. Bruwer. 2007a. "Balancing Act between Regionality and American Viticultural Areas (AVAs)." Journal of Wine Research. (18:3) pp. 163 -172.

Johnson, R. and J. Bruwer. 2007b. "Regional Brand Image and Perceived Wine Quality: The Consumer Perspective.” International Journal of Wine Business Research. (19:4) pp. 276-297.

Manning, P. 2013. "Craft beer becoming alternative to wine at the dinner table." FoxNews.com. January 24, 2013. Retrieved December 4, 2015, from http://www.foxnews.com/leisure.

MRI+ MediaMark. Fall 2013 Product Report. Alcoholic Beverages, Any Wines. Retrieved January 12, 2015, from MRI+ MediaMark.

Rickard, B.J., Jill J. McCluskey, R.W. Patterson. 2015. "Reputation tapping." European Review of Agricultural Economics. jbv003. pp. 1-27.

Schamel, G. and K. Anderson. 2003. "Wine Quality and Varietal, Regional and Winery Reputations: Hedonic Prices for Australia and New Zealand.” The Economic Record. (79:245) pp. 357-369. 
TTB. 2012. American Viticultural Area (AVA) Manual for Petitioners (TTB P 5120.4).

Retrieved April 21, 2015, from http://www.ttb.gov/wine/p51204_ava_manual.pdf.

van Ittersum, K., Matthew T.G. Meulenberg, and H.C.M. van Trijp. 2003. "Determinants of the accessibility of regional product information." Advances in Consumer Research. (30:1) pp. 180-187. 


\section{APPENDICES}

Appendix A: Wine Trade Survey Questionnaire (originally created in SurveyMonkey):

1. Which of the following describes your business? (Choose all that apply).

$\circ$ Retail wine shop

- Retail wine and spirits shop or liquor store

- Retail outlet for groceries and alcohol

- Retail chain store

- Restaurant

- Bar

- Wine bar

- Social club or Golf club

- Hotel

- Casino

- Transportation industry

○ Other (please specify)

2. Which of the following has your business sold in the past year?

○ Beer

- Craft Beer

- Wine

- Sparkling Wine/Champagne

- Spirits

- Craft Spirits

- None of the above

3. Which of the following varietals or blends have you purchased in the past year? (Choose all that apply).
- Cabernet Sauvignon
○ Chardonnay
- Merlot
- Pinot Grigio
- Pinot Noir
- Sauvignon Blanc
- Shiraz/Syrah
- Sparkling Wine/Champagne
- Rhone Blend
- Red Blend
- White Blend
- I don't sell wine

4. The following is a list of features buyers may look for when purchasing wines for their outlets. Please indicate the desirability of each feature to you when you purchase wine for your outlet by indicating how desirable it is using the following phrases: Extremely Desirable, Very Desirable, Somewhat Desirable, Slightly Desirable, Not At All Desirable. 


\begin{tabular}{|l|l|l|l|l|c|}
\hline & $\begin{array}{c}\text { Extremely } \\
\text { Desirable }\end{array}$ & $\begin{array}{c}\text { Very } \\
\text { Desirable }\end{array}$ & $\begin{array}{c}\text { Somewhat } \\
\text { Desirable }\end{array}$ & $\begin{array}{c}\text { Not Very } \\
\text { Desirable }\end{array}$ & $\begin{array}{c}\text { Not } \\
\text { Desirable } \\
\text { at All }\end{array}$ \\
\hline Premium quality product & & & & & \\
\hline $\begin{array}{l}\text { Produced from cool climate } \\
\text { grapes }\end{array}$ & & & & & \\
\hline High Wine Spectator Rating & & & & & \\
\hline $\begin{array}{l}\text { Grapes are from a respected } \\
\text { grape growing region }\end{array}$ & & & & & \\
\hline Sustainably produced & & & & & \\
\hline High Robert Parker Rating & & & & & \\
\hline From a well-known AVA & & & & & \\
\hline Produced in California & & & & & \\
\hline
\end{tabular}

5. How often do you:

\begin{tabular}{|c|c|c|c|c|c|}
\hline & Always & $\begin{array}{c}\text { Very } \\
\text { Often }\end{array}$ & $\begin{array}{c}\text { Somewhat } \\
\text { Often }\end{array}$ & $\begin{array}{c}\text { Not very } \\
\text { Often }\end{array}$ & Never \\
\hline $\begin{array}{c}\text { Make a decision to purchase one } \\
\text { wine versus another based on } \\
\text { where it was produced }\end{array}$ & & & & & \\
\hline
\end{tabular}

6. How familiar are you with the following wine grape growing regions?

\begin{tabular}{|l|l|l|l|l|l|}
\hline & $\begin{array}{c}\text { Extremely } \\
\text { Familiar }\end{array}$ & $\begin{array}{c}\text { Very } \\
\text { Familiar }\end{array}$ & $\begin{array}{c}\text { Somewhat } \\
\text { Familiar }\end{array}$ & $\begin{array}{c}\text { Not Very } \\
\text { Familiar }\end{array}$ & $\begin{array}{c}\text { Not } \\
\text { Familiar } \\
\text { at All }\end{array}$ \\
\hline Paso Robles & & & & & \\
\hline Arroyo Grande Valley & & & & & \\
\hline Sonoma County & & & & & \\
\hline Central Coast & & & & & \\
\hline Napa Valley & & & & & \\
\hline Edna Valley & & & & & \\
\hline Santa Rita Hills & & & & & \\
\hline
\end{tabular}

7. Based on your perceptions, how would rate the QUALITY of the wine produced in the following wine grape growing regions?

\begin{tabular}{|l|l|l|l|l|l|}
\hline & $\begin{array}{c}\text { Excellent } \\
\text { Quality }\end{array}$ & $\begin{array}{c}\text { Very } \\
\text { Good } \\
\text { Quality }\end{array}$ & $\begin{array}{c}\text { Somewhat } \\
\text { Good } \\
\text { Quality }\end{array}$ & $\begin{array}{c}\text { Not Very } \\
\text { Good } \\
\text { Quality }\end{array}$ & $\begin{array}{c}\text { Poor } \\
\text { Quality }\end{array}$ \\
\hline Paso Robles & & & & & \\
\hline Arroyo Grande Valley & & & & & \\
\hline Sonoma County & & & & & \\
\hline Central Coast & & & & & \\
\hline Napa Valley & & & & & \\
\hline Edna Valley & & & & & \\
\hline Santa Rita Hills & & & & & \\
\hline
\end{tabular}

8. In the past year when you purchased wine, from which of the following wine grape growing regions did the wine come from?
- Paso Robles
- Arroyo Grande Valley
- Sonoma County
- Central Coast 
- Napa Valley

- Edna Valley

- Santa Rita Hills

- None of the above

O Outside US (please specify)

I I DO NOT KNOW which grape growing regions my wine comes from

9. How appealing are the following names for a wine region on the San Luis Obispo County Coast?

\begin{tabular}{|l|l|l|l|l|c|}
\hline & $\begin{array}{c}\text { Extremely } \\
\text { Appealing }\end{array}$ & $\begin{array}{c}\text { Very } \\
\text { Appealing }\end{array}$ & $\begin{array}{c}\text { Somewhat } \\
\text { Appealing }\end{array}$ & $\begin{array}{c}\text { Not Very } \\
\text { Appealing }\end{array}$ & $\begin{array}{c}\text { Not } \\
\text { Appealing } \\
\text { at All }\end{array}$ \\
\hline Cabrillo Coast & & & & & \\
\hline Coastal San Luis Obispo County & & & & & \\
\hline San Luis Obispo Coast & & & & & \\
\hline SLO Coast & & & & & \\
\hline
\end{tabular}

10. Which ONE of the following names for a wine region on the San Luis Obispo County Coast is your favorite?

- Cabrillo Coast

- Coastal San Luis Obispo County

- San Luis Obispo Coast

- SLO Coast

11. Now after learning of a possible name change, based on your perceptions, which ONE of the following names for a wine region on the San Luis Obispo County Coast do you think BEST represents the QUALITY of wine?

- Cabrillo Coast

- San Luis Obispo Coast

- Arroyo Grande Valley

- Central Coast

- Coastal San Luis Obispo County

- Edna Valley

- SLO Coast

12. In which state is your business? (please specify) 
APPENDix B: Wine Consumer SuRVey Questionnaire (originally created in SurveyMonkey):

1. Which of the following ranges describes your age?
- Under 21
○ 21 to 24
○ 25 to 27
- 28 to 29
○ 30 to 32
○ 33 to 36
○ 37 to 39
○ 40 to 44
○ 45 to 49
○ 50 to 54
○ 55 to 64
○ 65 to 69
○ $70+$ years

2. Are you a:
- Local San Luis Obispo resident
- Local San Luis Obispo college student
- Other

3. Which of the following have you purchased in the past?
○ Beer
- Craft Beer
- Wine
- Sparkling Wine
- Spirits
- None of the above

4. Approximately how many bottles of wine do you typically buy per month at a retail outlet? Please enter 0 if none.

5. Approximately how much do you spend on wine in a typical month at a retail outlet? Please enter 0 if none.

6. Approximately how many glasses and/or bottles of wine do you typically buy per month at a restaurant or bar? Please enter 0 if none.

\begin{tabular}{|l|l|}
\hline Glasses (purchased by the glass) & \\
\hline Bottles & \\
\hline
\end{tabular}

7. In what price range do the majority of your wine bottle purchases fall when purchasing at a retail outlet $(750 \mathrm{ml}$ bottle size)? (Choose one).
○ $\$ 0.00-\$ 9.49$
○ $\$ 9.50-14.99$
- $\$ 15.00-24.99$
○ $\$ 25.00-\$ 49.99$
- $\$ 50.00-\$ 74.99$
- $\$ 75.00+$ 
8. Which of the following varietals or blends have you purchased in the past year. Choose all that apply.

$\begin{array}{ll}\circ & \text { Cabernet Sauvignon } \\ \circ & \text { Chardonnay } \\ \circ & \text { Pinot Noir } \\ \circ & \text { Red Blend } \\ \circ & \text { Merlot } \\ \circ & \text { Sauvignon Blanc } \\ \circ & \text { Pinot Grigio } \\ \circ & \text { Shiraz/Syrah } \\ \circ & \text { White Blend } \\ \circ & \text { Rhone Blend }\end{array}$

9. Desirable Factors When Purchasing Wine

\begin{tabular}{|l|l|l|l|l|l|}
\hline & $\begin{array}{c}\text { Extremely } \\
\text { Desirable }\end{array}$ & $\begin{array}{c}\text { Very } \\
\text { Desirable }\end{array}$ & $\begin{array}{c}\text { Somewhat } \\
\text { Desirable }\end{array}$ & $\begin{array}{c}\text { Not Very } \\
\text { Desirable }\end{array}$ & $\begin{array}{c}\text { Desirable } \\
\text { at All }\end{array}$ \\
\hline Premium quality product & & & & & \\
\hline Good value for the money & & & & & \\
\hline Varietal I like & & & & & \\
\hline $\begin{array}{l}\text { Label identifies the growing } \\
\text { region }\end{array}$ & & & & & \\
\hline Sustainably produced & & & & & \\
\hline From a respected region & & & & & \\
\hline
\end{tabular}

10. How often do you:

\begin{tabular}{|c|l|l|l|l|l|}
\hline $\begin{array}{c}\text { Read the label of a wine bottle to } \\
\text { learn where the wine was } \\
\text { produced }\end{array}$ & Always & $\begin{array}{c}\text { Very } \\
\text { Often }\end{array}$ & $\begin{array}{c}\text { Somewhat } \\
\text { Often }\end{array}$ & $\begin{array}{c}\text { Not very } \\
\text { Often }\end{array}$ & Never \\
\hline $\begin{array}{c}\text { Make a decision to purchase one } \\
\text { wine versus another based on } \\
\text { where it was produced }\end{array}$ & & & & & \\
\hline
\end{tabular}

11. How familiar are you with the following wine grape growing regions?

\begin{tabular}{|l|l|l|l|l|l|}
\hline & $\begin{array}{c}\text { Extremely } \\
\text { Familiar }\end{array}$ & $\begin{array}{c}\text { Very } \\
\text { Familiar }\end{array}$ & $\begin{array}{c}\text { Somewhat } \\
\text { Familiar }\end{array}$ & $\begin{array}{c}\text { Not Very } \\
\text { Familiar }\end{array}$ & $\begin{array}{c}\text { Fot } \\
\text { at All }\end{array}$ \\
\hline Paso Robles & & & & & \\
\hline Arroyo Grande Valley & & & & & \\
\hline Sonoma County & & & & & \\
\hline Central Coast & & & & & \\
\hline Napa Valley & & & & & \\
\hline Edna Valley & & & & & \\
\hline Santa Rita Hills & & & & & \\
\hline York Mountain & & & & & \\
\hline Sierra Nevada Foothills & & & & \\
\hline
\end{tabular}

12. Based on your perceptions, how would you rate the QUALITY of the wine produced in the following wine grape growing regions? 


\begin{tabular}{|l|l|l|l|l|l|}
\hline & $\begin{array}{c}\text { Excellent } \\
\text { Quality }\end{array}$ & $\begin{array}{c}\text { Very } \\
\text { Good } \\
\text { Quality }\end{array}$ & $\begin{array}{c}\text { Somewhat } \\
\text { Good } \\
\text { Quality }\end{array}$ & $\begin{array}{c}\text { Not Very } \\
\text { Good } \\
\text { Quality }\end{array}$ & $\begin{array}{c}\text { Poor } \\
\text { Quality }\end{array}$ \\
\hline Paso Robles & & & & & \\
\hline Arroyo Grande Valley & & & & & \\
\hline Sonoma County & & & & & \\
\hline Central Coast & & & & & \\
\hline Napa Valley & & & & & \\
\hline Edna Valley & & & & & \\
\hline Santa Rita Hills & & & & & \\
\hline York Mountain & & & & & \\
\hline Sierra Nevada Foothills & & & & & \\
\hline
\end{tabular}

13. In the past year when you purchased wine, from which of the following wine grape growing regions did the wine come from?

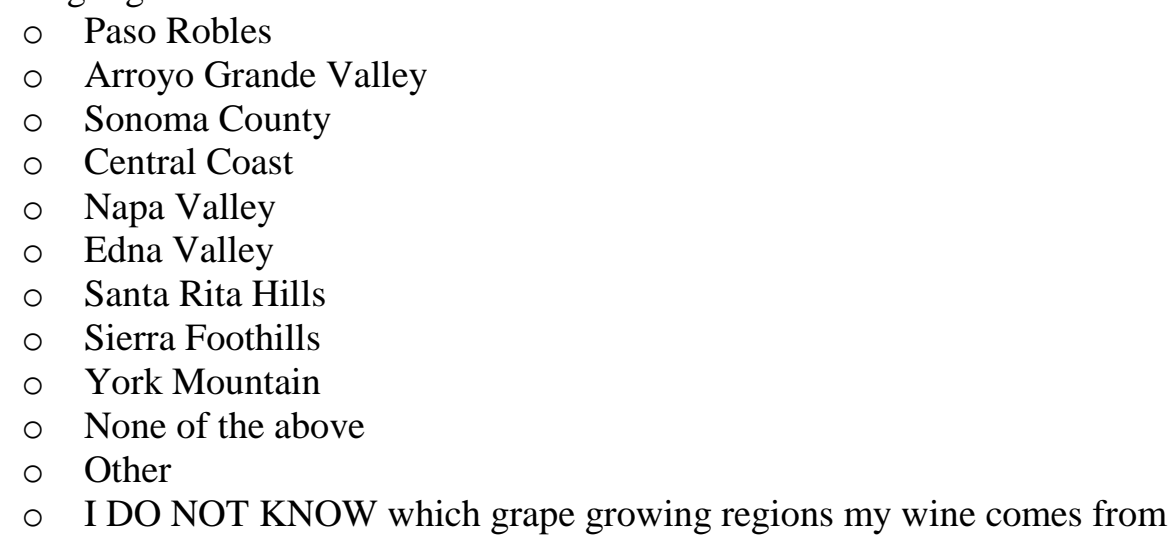

14. How appealing are the following names for a wine region on the San Luis Obispo Count Coast?

\begin{tabular}{|l|l|l|l|l|c|}
\hline & $\begin{array}{c}\text { Extremely } \\
\text { Appealing }\end{array}$ & $\begin{array}{c}\text { Very } \\
\text { Appealing }\end{array}$ & $\begin{array}{c}\text { Somewhat } \\
\text { Appealing }\end{array}$ & $\begin{array}{c}\text { Not Very } \\
\text { Appealing }\end{array}$ & $\begin{array}{c}\text { Not } \\
\text { Appealing } \\
\text { at All }\end{array}$ \\
\hline Coastal San Luis Obispo County & & & & & \\
\hline San Luis Obispo Coast & & & & & \\
\hline SLO Coast & & & & & \\
\hline
\end{tabular}

15. Which ONE of the following names for a wine region on the San Luis Obispo County Coast is your favorite?
- San Luis Obispo Coast
- SLO Coast
- Coastal San Luis Obispo County

16. Now after learning of a possible name change, based on your perceptions, how would you rate the QUALITY of the wine produced in the following grape growing regions?

\begin{tabular}{|l|l|l|l|l|l|}
\hline & $\begin{array}{c}\text { Excellent } \\
\text { Quality }\end{array}$ & $\begin{array}{c}\text { Very } \\
\text { Good } \\
\text { Quality }\end{array}$ & $\begin{array}{c}\text { Somewhat } \\
\text { Good } \\
\text { Quality }\end{array}$ & $\begin{array}{c}\text { Not Very } \\
\text { Good } \\
\text { Quality }\end{array}$ & $\begin{array}{c}\text { Poor } \\
\text { Quality }\end{array}$ \\
\hline Arroyo Grande Valley & & & & & \\
\hline San Luis Obispo Coast & & & & & \\
\hline Central Coast & & & & & \\
\hline Coastal San Luis Obispo County & & & & & \\
\hline Edna Valley & & & & & \\
\hline SLO Coast & & & & & \\
\hline
\end{tabular}


17. Now after learning of a possible name change, based on your perceptions, which ONE of the following names for a wine region on the San Luis Obispo County Coast do you think BEST represents the highest QUALITY of wine?

- San Luis Obispo Coast

- Edna Valley

- Coastal San Luis Obispo County

- Central Coast

- SLO Coast

- Arroyo Grande Valley

18. Do you have any other suggestions for a name for a wine region that is in the San Luis Obispo Coast that will represent high quality wine?

19. Which of the following do you do or use regularly to get information about wine?

(Choose all that apply)

$\begin{array}{ll}\circ & \text { Blogs } \\ \circ & \text { Facebook } \\ \circ & \text { Family or Friends } \\ \circ & \text { Food magazines (Print) } \\ \circ & \text { Instagram } \\ \circ & \text { Online Newspapers } \\ \circ & \text { Online wine magazines } \\ \circ & \text { Other Online Wine } \\ & \text { Websites } \\ \circ & \text { Pinterest } \\ \circ & \text { Print Newspapers } \\ \circ & \text { QR Codes } \\ \circ & \text { Servers/Sommeliers at } \\ & \text { restaurants } \\ \circ & \text { Sunset Magazine (Print) }\end{array}$

○ Trip Advisor

- Twitter

- Visits to Wineries

- Web search

- Wine Apps

- Wine Bars

- Wine Club Information

- Wine Events

○ Wine magazines (Print)

- Wine Spectator

- Wine Trail Maps

○ Winery Newsletters

○ Winery Websites

- YouTube

20. Are you?

\begin{tabular}{|l|l|}
\hline Male & \\
\hline Female & \\
\hline
\end{tabular}

21. Do you have children under the age of 18 living at home?

\begin{tabular}{|l|l|}
\hline Yes & \\
\hline No & \\
\hline
\end{tabular}

22. Are you...
- Married
- Living with a partner
- Single
- Widowed

23. Please tell me the level of education you have completed (Circle only one).
a. Grade school or Less
b. Some High School
c. High School Graduate
d. Some College
e. College Graduate 


\section{f. Post-Graduation Work}

24. Are you employed?

- Employed, Full Time

- Employed, Part Time

- Not Employed or Retired

25. Are you or a family member in the wine industry?

- I work or previously worked in the wine industry

- A family member works or previously worked in the wine industry

- None of the above

26. Which of the following ranges describes your household income before taxes?
a. Under $\$ 20,000$
b. $\$ 20,000$ to $\$ 24,999$
c. $\$ 25,000$ to $\$ 29,999$
d. $\$ 30,000$ to $\$ 34,999$
e. $\$ 35,000$ to $\$ 39,999$
f. $\$ 40,000$ to $\$ 49,999$
g. $\$ 50,000$ to $\$ 59,999$
h. $\$ 60,000$ to $\$ 74,999$
i. $\$ 75,000$ to $\$ 149,999$
j. $\$ 150,000$ or more

27. Are you from:

$\begin{array}{ll}\circ & \text { San Luis Obispo County, CA } \\ \circ & \text { North of Bay Area, CA } \\ \circ & \text { Bay Area, CA } \\ \circ & \text { Sacramento Area, CA } \\ \circ & \text { Central Valley, CA }\end{array}$

- East Coast, US

- Midwest, US

- West not California, US

- South, US

- Outside US

28. Did you answer this survey from:

- A personal interview with a Cal Poly Student-WVIT 343 (choose this answer)

○ Other

29. What is your Interview ID?

30. What Quarter did you take this survey?

○ Fall 2014

- Winter 2015 